\title{
Ezra Ayers Carman: The Gatekeeper of Memory at Antietam National Battlefield
}

Richard A. Hulver

West Virginia University

Follow this and additional works at: https://researchrepository.wvu.edu/etd

\section{Recommended Citation}

Hulver, Richard A., "Ezra Ayers Carman: The Gatekeeper of Memory at Antietam National Battlefield" (2011). Graduate Theses, Dissertations, and Problem Reports. 746.

https://researchrepository.wvu.edu/etd/746

This Thesis is protected by copyright and/or related rights. It has been brought to you by the The Research Repository @ WVU with permission from the rights-holder(s). You are free to use this Thesis in any way that is permitted by the copyright and related rights legislation that applies to your use. For other uses you must obtain permission from the rights-holder(s) directly, unless additional rights are indicated by a Creative Commons license in the record and/ or on the work itself. This Thesis has been accepted for inclusion in WVU Graduate Theses, Dissertations, and Problem Reports collection by an authorized administrator of The Research Repository @ WVU. For more information, please contact researchrepository@mail.wvu.edu. 
Ezra Ayers Carman: The Gatekeeper of Memory at Antietam National Battlefield

Richard A. Hulver

\author{
Thesis submitted to the \\ Eberly College of Arts and Sciences \\ at West Virginia University \\ in partial fulfillment of the requirements \\ for the degree of \\ Master of Arts \\ In \\ History \\ Peter Carmichael, Ph.D., Chair \\ Joshua Arthurs, Ph.D. \\ James Siekmeier, PhD. \\ Department of History \\ Morgantown, West Virginia \\ 2011
}

Keywords: Ezra A. Carman; Carman Correspondence; Antietam; Antietam Board;

Antietam National Battlefield; Antietam Studies; Civil War Memory; Historical Processes

Copyright 2011 Richard A. Hulver 


\section{Abstract \\ Ezra Ayers Carman: The Gatekeeper of Memory at Antietam National Battlefield}

Richard A. Hulver

Ezra Ayers Carman was a veteran of Antietam who was employed by the War Department in the last decade of the nineteenth century to write the official history of that battle. As an historian, Carman acted as a gatekeeper of the official memory at Antietam. He created scaffolding in which veterans could remember tactical/military aspects of their participation in the battle of Antietam. Once his framework for memory was set, Carman opened up extensive correspondence with veterans. He then had the responsibility of sifting through the incoming memories and choosing those he would use to create his official history. The historical process that Carman used demonstrates that historical memory often takes place at the most basic levels of society and then works its way up. Essentially, Carman initiated private conversations and took those memories to make a national interpretation. The product of Carman's work reveals that core ideas of Americanism are found through remembrance of inflated heroism in warfare. Dissenting memories that came to Carman often focused on the realistic and horrific aspects of war, these memories were silenced and left out of the official history. The Federal government adopted methods similar to those Carman used as subsequent U.S. wars were commemorated nationally. 


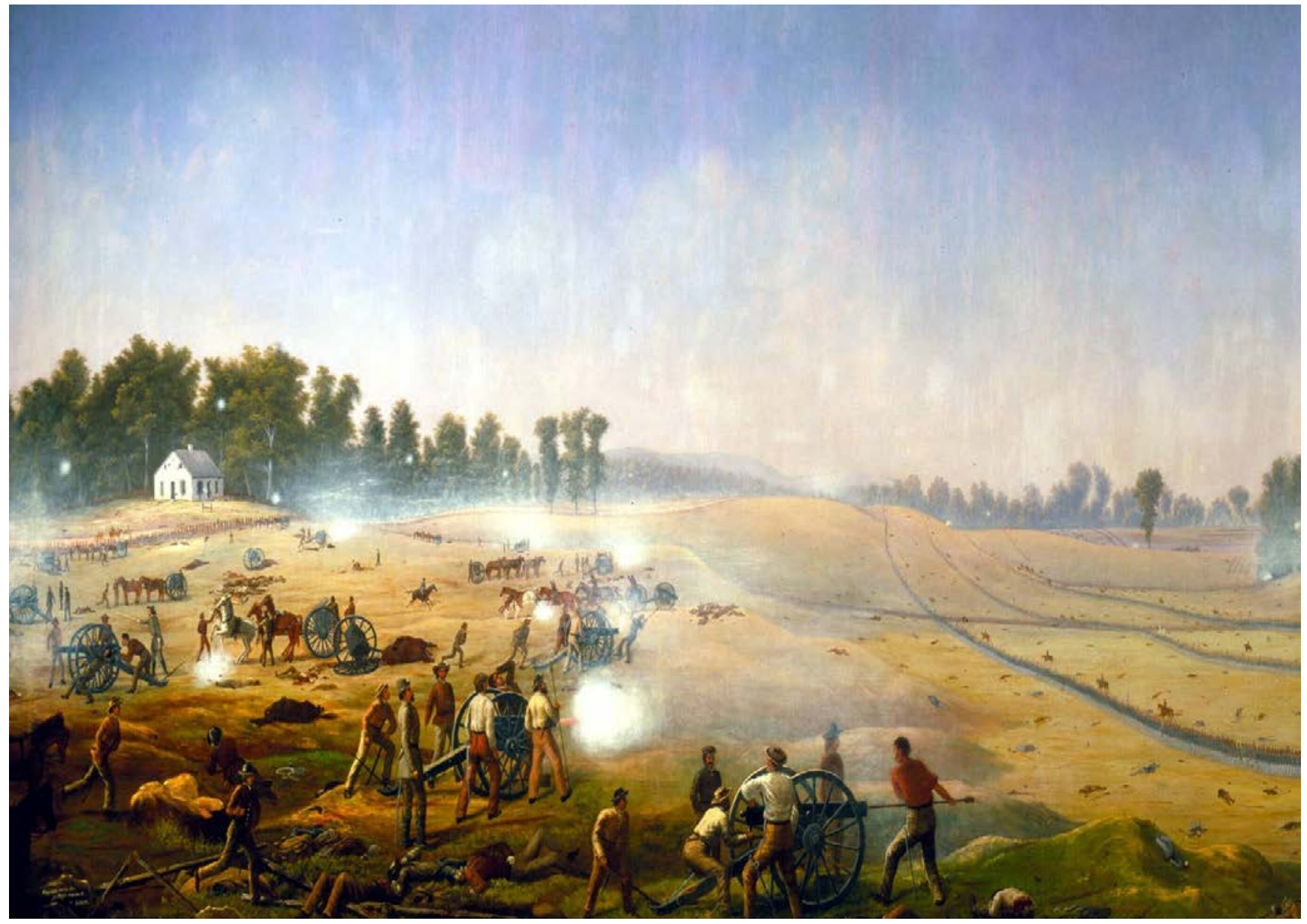

John Hope, "Artillery Hell." Courtesy of Antietam National Battlefield. 


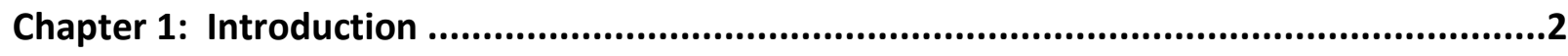

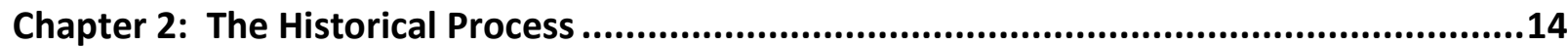

Chapter 3: Dissenting Memories ......................................................................30

Chapter 4: A National Narrative and Conforming Memories .......................................39

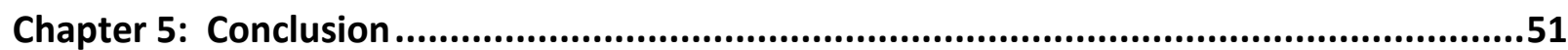

\section{List of Photographs}

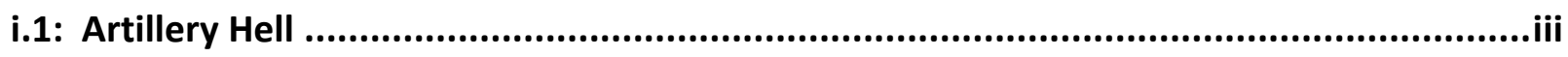

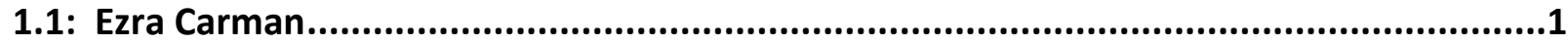

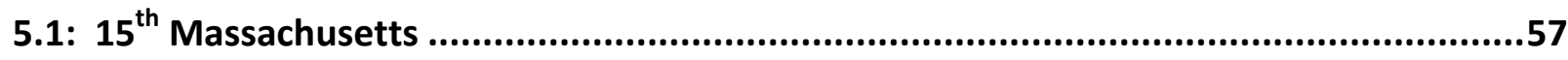

5.2: McLaughlin POWs ..................................................................................64 


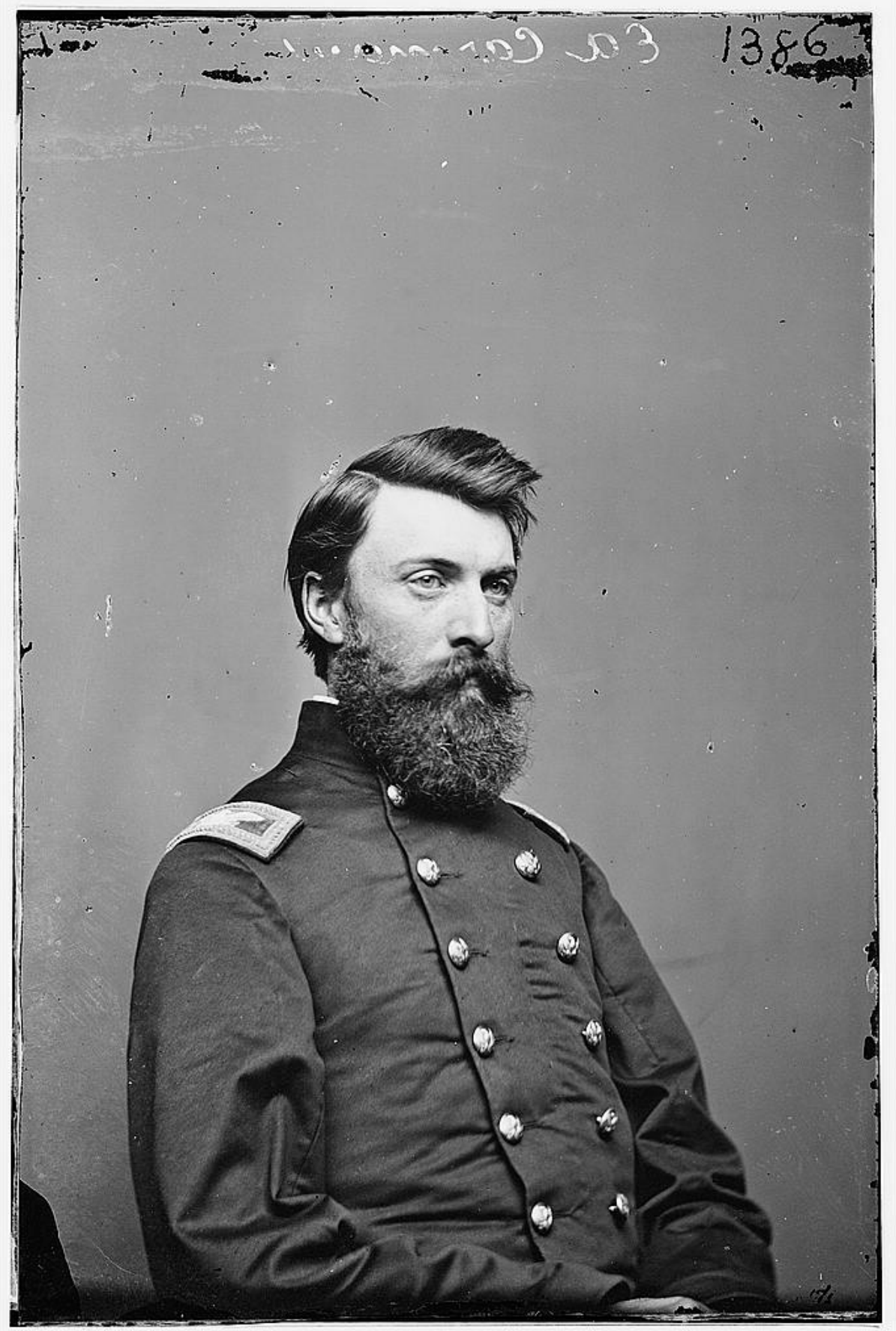

Ezra Ayers Carman as colonel of the Thirteenth New Jersey Infantry during the Civil War. Courtesy of Library of Congress Digital Collection. 


\section{Chapter 1: Introduction}

On the morning of September 17, 1862, twenty-eight year old Ezra Ayers Carman led green soldiers of the newly formed Thirteenth New Jersey Infantry into battle through the cornfields and the East Woods of Sharpsburg, Maryland. Although the unit's multiple advances were repulsed by Confederate defenders and it became involved in a friendly fire incident, it was acknowledged for exhibiting bravery in battle. Colonel Carman was thrown from his horse late in the fighting and forced to retire to a field hospital in the rear. Between front line combat and a field hospital visit on that macabre day, he bore witness to some of the most horrific and dehumanizing episodes that a man could ever experience. His use of the label "a carnival of death and suffering" to describe the battle gives validity to this assumption. As do descriptive scenes he painted in postwar speeches of fields "moistened and crimsoned with human blood. . .$^{1}$ Images of unimaginable carnage were assuredly burned into Carman's memory and starkly contrasted with his daily post-war life thereafter.

Carman did not choose to detach himself from that horrible day though. Something about his experience as a small cog in McClellan's Army of the Potomac enticed him to chronicle the entire Maryland Campaign. In the days following the battle he started immersing himself in its details and began interviewing Union soldiers, Confederate prisoners, and local citizens who had witnessed the spectacle. He immediately fixated on the battle and went into a period of deciphering. His ultimate goal was to complete accurate maps of the battle and, eventually, a narrative history. Continuation of the war and the demands of life removed Carman from

\footnotetext{
1 “E.A. Carman Accepting $34^{\text {th }}$ NY Monument." Taken from L.N. Chapin, A brief history of the Thirty-fourth regiment, N. Y. S. V: Embracing a Complete Roster of all Officers and Men and a Full Account of the Dedication of the Monument on the Battlefield of Antietam September 17, 1902 (Veterans Association of the Thirty-Forth Regiment Volunteer Infantry, State of New York, 1902).
} 
Sharpsburg shortly after he began his work as an amateur historian. Yet, an appointment by

the New Jersey governor in 1866 placed him as the state's representative on the Antietam

National Cemetery Association and kept the battle and location constantly in his thoughts. ${ }^{2}$ The

Federal government's decision to establish military parks in the decades following this initial

appointment led to Carman's eventual assignment as the historical expert of Antietam and

permanently secured his spot in Antietam's story. Carman's contributions to Antietam as both

a soldier and historian leave a compelling case study for memory scholars to analyze.

Memory is not a concept that historians can fit neatly into a narrative because it is not a

reproduction of the lived past; instead it is itself a living process that continually labors to

construct and order that past. ${ }^{3}$ Regardless of the individuality of memories, they are still

\footnotetext{
${ }^{2}$ There are currently two published versions of Carman's original manuscript. Ezra Ayers Carman, ed. Joseph Pierro, The Maryland Campaign of September 1862: Ezra A.Carman's Definitive Study of the Union and Confederate Armies at Antietam (New York: Routledge Press, 2008), ix. Also, Tom Clemens, The Maryland Campaign of September 1862, Vol. I: South Mountain (Savas Beatie, 2010). In 1877 the U.S. War Department assumed control of the Cemetery Association and the trustees were no longer needed.

${ }^{3}$ There are numerous works addressing the theoretical groundwork of historical memory, but for this article the author has primarily focused on the work of French scholar Pierre Nora, "Between Memory and History: Les Lieux de Memoire, "Representations, No. 26, Special Issue: Memory and Counter-Memory (Spring, 1989), 7-24, this essay explains the difference between history and memory and laid the groundwork for how many memory scholars approach their subjects. Both, W. Fitzhugh Brundage, "No Deed but Memory," taken from Where These Memories Grow: History, Memory, and Southern Identity (Chapel Hill: UNC Press, 2000), and Michael Kammen, Mystic Chords of Memory: The Transformation of Tradition in American Culture (New York: Knopf, 1991) also provided a conceptual framework for memory studies. The author was also influenced by the theoretical work presented by recent European scholars studying the complexities of German WWII memory regarding commemoration for their soldier dead of World War II-the issue of how to remember the Nazi regime stands as an extraordinary case study for memory scholars to turn. Additionally, he was guided by the theoretical ideas in Peter Burke, What is Cultural History? (Cambridge: Polity Press, 2008 2ed), Willie Thompson, Postmodernism and History (New York: Palgrave Macmillan 2004), T. Jackson Lears, "The Concept of Cultural Hegemony," American Historical Review (1985), and Daniel Wickberg, "What is the History of Sensibilities? On Cultural Histories, Old and New," The American Historical Review (2004). Michel-Rolph Trouillot, Silencing the Past: Power and the Production of History (Boston: Beacon Press, 1995) presented a post-modernist argument dealing with the actual historical process's implications on memory. Trouillot's work also explicitly discussed historical silences and helped the author add focus to Carman's work.

For a broad overview of Civil War memory historiography and examples of scholars working with concepts of historical memory and commemoration see Matthew J. Grow, "The Shadow of the Civil War: A Historiography of Civil War Memory," American Nineteenth Century History, Vol. 4, No. 2, Summer 2003. Grow's historiographical essay is somewhat dated, but it effectively shows the trajectory of Civil War memory studies. It also gives insight
} 
heavily bound by context. Memory is often conceptualized as taking shape at the upper echelons of society in smoked-filled rooms over gentlemanly debate. More often, it is crudely navigated on a personal level through countless informal occurrences in everyday life. The correspondence between the War Department's historical expert at Antietam, Ezra Ayers

into the direction the field was headed at the time. Civil War memory studies that specifically look at issues of race and memory include the seminal work by David Blight, Race and Reunion: The Civil War in American Memory (Cambridge, Massachusetts: Harvard University Press, 2001) and Kirk Savage, Standing Soldiers, Kneeling Slaves: Race, War, and Monument in Nineteenth Century America (Princeton University Press, 1997. For memory studies looking at issues of gendered memory as a means to reunite the country see Nina Silber, The Romance of Reunion: Northerners and the South, 1865-1900 (Chapel Hill: UNC Press, 1993). Aspects of the Lost Cause mythos are aptly handled in Garry Gallagher and Alan Nolan, eds., The Myth of the Lost Cause and Civil War History ( Indianapolis: Indiana University Press, 2000) and Edward Ayers, What Caused the Civil War? Reflections on the South and Southern History (New York and London: WW Norton \& Co., 2005). To broadly see how collective memory of American wars forms ideas of Americanism look to G. Kurt Piehler, Remembering War the American Way (Washington, D.C.: Smithsonian Press, 1995). Memory studies of single battles and single engagements are also a large part of the Civil War historiography, one of the best examples of these is Carol Reardon, Pickett's Charge in History and in Memory (Chapel Hill: UNC Press, 1997). Both Alice Fahs, The Imagined Civil War: Popular Literature of the North \& South, 1861-1865 (Chapel Hill: UNC Press, 2001) and Paul Fussell, The Great War and Modern Memory (New York and London: Oxford University Press, 1975) demonstrate how popular culture/literature influence memory of wars and are influenced by soldiers' memories. Also invaluable were James McPherson, For Cause \& Comrades: Why Men Fought in the Civil War (New York and Oxford: Oxford University Press, 1997) \& Crossroads of Freedom: Antietam (Oxford: Oxford University Press, 2002), Earl J. Hess, The Union Soldier in Battle (Lawrence: The University Press of Kansas, 1997), Gerald F. Linderman, Embattled Courage: The Experience of Combat in the American Civil War (New York: Free Press, 1987), Garry Gallagher ed., The Antietam Campaign (Chapel Hill: UNC Press, 1999) among these essays Lesley J. Gordon "All Who Went into that Battle Were Heroes: Remembering the $16^{\text {th }}$ Regiment Connecticut Volunteers at Antietam," was particularly useful in this study. Although the focus of this paper is memory and the bulk of Antietam material analyzed was primary source material, the setting of Antietam made it necessary to rely on several works for basic information. Among the most heavily relied on were Stephen Sears, Landscape Turned Red: The Battle of Antietam (New Haven and New York: Tickner and Fields, 1983) and Ezra Ayers Carman, The Maryland Campaign of September 1862 (New York: Routledge, 2008) ed. Joseph Pierro, and Tom Clemens, The Maryland Campaign of September 1862, Vol. I: South Mountain (Publisher: Savas Beatie, 2010). Clemens's work will eventually be a two volume treatment of the Carman manuscript. It is anticipated to add much more depth to Carman's work than the Pierro accomplished. Dr. Clemen's also maintains a blog and often publishes Carman correspondence for his readers. Several of these letters were used in the author's analysis of Carman as a gatekeeper of memory. Finally, much of the Antietam research done for this project was undertaken at the Antietam Archives in Sharpsburg, MD and at the National Archives in Washington, DC. Chief Historian Ted Alexander was instrumental in giving direction toward the right collections, as was Dr. Clemens, who many refer to as Mr. Antietam and the Carman expert.

While the Civil war laid the basis for most of this paper, the concluding chapter of this work looked at the American Battle Monuments Commission in comparison to what Ezra Carman achieved at Antietam. The bulk of this research was conducted by the author while enrolled at Shepherd University (Shepherdstown, WV) while studying as a George C. Marshall fellow for the George C. Marshall Research Foundation in 2009. This research is available in the George C. Marshall Research Library on campus at the Virginia Military Institute, Lexington, VA and also available in the "Honors Thesis" collection at Shepherd University's Scarborough Library. It is entitled, "A Faith Kept: The Leadership of John Pershing and George Marshall in the American Battle Monuments Commission." 
Carman, and other Maryland Campaign veterans throughout the late nineteenth century demonstrates memory construction from the ground up and its convergence into a single story. Carman was an historical agent, historian, archivist, and gatekeeper who developed scaffolding in which veterans could easily remember. Without his guidance and structure, the voices of veterans' memories would have remained outside the story of Antietam. His work at Antietam facilitated a national conversation about the battle with veterans from both sides. He desired to find purity and a higher purpose in the war's bloodiest day by encouraging his fellow soldiers to reduce their experience to tactical maneuvers in which they could all emerge from the fog of war as strong, decisive, and noble figures.

The goal of the War Department was to provide an interpretation of Antietam that all veterans could be proud of and that the nation could unite around. Insufficient sources to create a detailed account of the battle required consultation with the memories of participants to fill large gaps in the narrative. The process of recalling these memories provided their owners' opportunity to define themselves as individuals, while simultaneously defining cultural notions of what characteristics made an American. The presence of a sentry was needed as decade old memories came before the gates of history. Carman assumed this role. Memories of dissent were silenced and shelved. Those that coalesced and fit an agenda of reunion were allowed to become part of his historical interpretation. Ultimately this narrative created a memory that primarily secured Antietam's military legacy as the bloodiest day in American history, and not the battle that ushered in emancipation

For decades memory studies have been firmly entrenched in the Civil War historiography. Much of this work is a result of scholars outside of the field who have 
formulated interpretative frameworks and methodological approaches for students of historical memory to follow. Memory monographs of the Civil War have been published that address issues of race, gender, combat experience, popular literature, single battles, memorial landscapes, individual historical actors, and a multitude of other historical phenomenon. Although memory has proven itself to be a useful means for historians to engage a subject, it has constantly been under attack. Critics of Civil War memory studies often acknowledge some usefulness in them, but primarily dismiss them as being trendy products that shed more light on postwar years than the war itself. ${ }^{4}$ This can be remedied, however. It is highly unlikely that Civil War memory studies have reached their pinnacle of usefulness. The large canon cannot sit idly on bookshelves without careful interpretation and revision from future historians. Within the plethora of memory studies are gaps that must be filled and the seeds for future scholarship. Gerald Linderman's and David Blight's treatment of Civil War veterans' memories have laid the foundation for this study, which poses alterations of their interpretative models. Of primary concern is the fact that both men view memory as being the helpless victim of prevailing forces in the top tiers of society. The framework that they place memory in is devoid of human agency and the will of the historical actor.

\footnotetext{
${ }^{4}$ Christopher Phillips, "Shadow War: Border Women and Families in the Crucible of Dissent." (Paper presented at West Virginia University public lecture on 1/14/2011). In response to a question regarding his work, Dr. Phillips gave a lengthy response on the current state of Civil War history and the limited use that memory studies now have toward the field. Also, Matthew J. Grow, "The Shadow of the Civil War: A Historiography of Civil War Memory," American Nineteenth Century History, Vol. 4, No. 2, Summer 2003, 98. This historiographical essay does an excellent job of explaining the current state of memory studies at the time it was written and is reflective of Dr. Phillips's critique of memory studies.
} 
Historian Gerald Linderman has described memories of Civil War veterans as travelling through two distinct phases- "hibernation and revival." ${ }^{5}$ Each of these periods was dictated not from the veteran's wishes, but from society's. Hibernation took place immediately following the war and roughly stretched into the1880s. Linderman views this time as a period in which soldiers were alienated from their wartime experience and sought to repress the horrors of combat in order to speedily reintegrate into society. ${ }^{6}$ In the 1880 s a revival took place. Memories of the Civil War became a commodity to society at large, and veterans' memoirs found a prominent position within the literary canon.

David Blight views this categorization of veterans' memory as too clear-cut. Instead, he constructs a more open timeline for memory. In Blight's analysis, the memory of veterans went into a state of incubation immediately following the war. ${ }^{7}$ During this incubation they seem to have remained somewhat insulated from influences of society, but still were at the mercy of higher powers. They underwent a lengthy period of solitary reckoning, and then emerged as a cultural force when the public desired to hear them. Both historians' ideas regarding postwar memory have advanced the field of Civil War memory in a forward direction, yet they both create a Civil War memory that largely departs from the actual war and is more telling of society in the latter part of the 1890 s than in the 1860 s. Additionally, both historians focus primarily on Northern memory, thus failing to place their work in a national context.

In both historians' cases the memories lack a facilitator, or mediator. This is the reason that they lack specificity and a direct link to the war years. Failure to acknowledge the presence

\footnotetext{
${ }^{5}$ Gerald Linderman, Embattled Courage: The Experience of Combat in the American Civil War (New York: The Free Press, 1987), 266-297.

6 Ibid., 268.

${ }^{7}$ David Blight, Race and Reunion: The Civil War in American Memory (Harvard University Press, 2001 ), 150.
} 
of facilitators also obstructs Blight and Linderman from realizing the individual agency of historical actors as they willingly moved their memories into a public narrative. Skilled mediators of memory are able to guide remembrance into specific realms. Their prompts bring clarity to memory that would be nearly impossible to have with disorderly recollection. This phenomenon should hold a prominent position in studies of memory.

Ezra Carman was a mediator of Northern and Southern recollections of one battle, Antietam. His correspondence with veterans at the turn of the nineteenth century demonstrates that once prompted with specific inquiries, original meanings of war and combat were prominent in veterans' memories over two decades after soldiers left the field. They simply needed a framework to speak through, or against. While threads of 1890 s culture are certainly present in the correspondence, they are not always dominant. Veterans putting pen to paper in response to Carman's specific questions were opening a time capsule to the war years. Focus on Antietam grounds memory in practical application by explicitly connecting memory to one wartime event.

Carman initiated a specific series of questions that jump started veterans memories. They began thinking within his framework and certain questions would trigger memories hidden in their unconsciousness. Once the trigger happened and the unconscious became conscious and old memories would pass the mind's inner gatekeeper and emerge as a legitimate memory of a specific time. Freudian theory adds clarity to this concept. Freud believed in the idea that within human minds a sort of gatekeeper presence existed that 
controlled certain memories and feelings presented to others. ${ }^{8}$ Recollections of some events or facts remained present in the mind, but existed more in the realm of unconsciousness. Put simply, certain memories, often older ones, were buried so deeply and guarded so closely by the gatekeeper that they would never be able to be accessed. But, other memories were immediately available upon request. Most memories rested in a state of limbo between the two extremes and merely required a trigger to jump start remembering and allow passage by the watchman into the consciousness. ${ }^{9}$ If this theory is accepted it is difficult to consider memories being incapable of providing a window into the time that they were formed. Once formed, they essentially remained untouched, just inaccessible until some trigger brought them to the front of consciousness.

Another aspect of Carman's work that can break new ground in a memory study is an understanding of the actual process of making history. Carman was primarily a writer of history and collector of sources. What he chose to accept and exclude from his narrative demonstrates the incredible influence that historical actors had in willing their own representations for the future-both Carman and his respondents were doing this. A recent study of the process of making history argues that "history is not merely a project of fact-retrieval, but also a set of complex processes of selection, interpretations, and even creative invention." ${ }^{10}$ The process of history is influenced by the historian's "personal encounter with the archive, the history of the archive itself, and the pressure of the contemporary moment. . .."11 Carman's work is an

\footnotetext{
${ }^{8}$ Michael Kahn, Basic Freud: Psychoanalytic Thought for the Twenty First Century (New York: Basic Books, 2002), 20.

${ }^{9} \mathrm{Ibid}$. Kahn is a psychiatrist that provides a very accessible summary of Freud's methods and theories. Much of the Freudian theory used here comes from the examples that Kahn puts forth.

${ }^{10}$ Antoinette Burton, Archive Stories: Facts, Fictions, and the Writing of History (Duke University Press, 2005), 7-8. ${ }^{11}$ Ibid.
} 
excellent example of this kind of process. To accomplish his work he relied heavily on published accounts of the Civil War such as the Official Records, histories of the war, and veterans' memoirs. These were all products of some other historian's work. By corresponding with veterans and using their words in his historical project, Carman himself became the historian, archivist, and caretaker of memory. He filtered over other people's histories, and often used them as secondary or primary sources in his manuscript. ${ }^{12}$ He also created his own sources by engaging in conversation with veterans. Some of these were used in his narrative, but even the ones that were not were left in a sort of archive. Carman's decision to keep the letters he would not use created opportunities for future historians that were unknown to Carman at the time.

The historian's encounter with archives and sources has major implications and needs to be developed further. For instance, the act of silencing memories and stories was a large part of Carman's work. Michelle Trouillot, a prominent Haitian scholar recently addressed the issue of historical silence. He concludes that silences are a part of the historical process in four critical moments: "the making of sources (fact creation), the making of archives (fact assembly), the making of narrative (fact retrieval), and the making history (retrospective thinking). ${ }^{13}$ Each of these moments were encountered by Carman, and in some way actually overseen by him. It is of the upmost importance to understand that Carman's decisions of inclusion or exclusion momentarily muted some historical agents. The non-presence of these

\footnotetext{
${ }^{12}$ Carman frequently uses other historians work to add context to his manuscript on Antietam. Often, he used lengthy block quotes of others' work. Both editors of the manuscript, Joseph Pierro and Tom Clemens, made an incredible effort to check all of the sources that Carman used, and footnote them appropriately. The academic standard with regards to citing sources was much less stringent while Carman worked, and his sources were often not noted as well as they should have been by contemporary standards.

${ }^{13}$ Michel-Rolph Trouillot, Silencing the Past: Power and the Production of History (Boston: Beacon Press, 1995), 26-27.
} 
voices in his work does not mean that they cannot be found. Attention should be paid to their absences, and his history should be deconstructed to determine the varying degrees of silencing. If this is done it is possible to understand that all historical narratives are nothing more than a specific "bundle of silences." ${ }^{14}$ Acceptance of this allows for Carman's work to be viewed in new perspective. Not only is the actual written work he left important, but so are the interpretive gaps present. Because Carman left records of his correspondence/memories it is possible to sift through his work and listen to his silences. These are among the most revealing pieces of Carman's case study, and will be discussed in the chapter on dissent.

This entire process indicates that the hibernation or incubation described by Linderman and Blight are inadequate descriptors that tell more of a top-down story of memory. Rather, veterans' memories did undergo some construction and alteration, but they essentially remembered their lived experiences once a trigger was produced. Furthermore, memories produced by a trigger had to undergo an additional test of becoming heard and not silenced. Hibernation or incubation oversimplifies what is really a complex chain of events happening on the most basic levels of human life and they strip historical actors of their individual will. Ezra Carman's work at Antietam provides a view to a specific episode in the Civil War while simultaneously opening a window into the larger tapestry of America at the turn of the century. Much of this American tapestry is revealed by Carman's role as an historian employed by the Federal government. The Carman case study demonstrates how the federal government used a historian to create the official interpretation of the battle. Ezra Carman's work for the War Department allows movement beyond the purely cultural battle for memory and into the

\footnotetext{
14 Ibid., 27.
} 
political realm. Carman's actions and decisions as a War Department historian are reflective of the United States Government's desires. Thus, Carman's forum for veteran memories to gather, and his ensuing treatment of these memories, is extremely revelatory. The process that Carman adopted effectively demonstrates the ways that American government at the turn of the century preferred to interact and influence the public and popular culture.

The historical work at Antietam also reveals U.S. diplomatic undertones on the eve of the twentieth century because the definitions of Americanism created in the Antietam narrative became the way the United States wished to be viewed internationally. It stands as an early instance of the American cultural notion that national identity and pride is forged through bravery in war. The historical products created by Carman serve as examples of the American penchant for defining itself through its military engagements. This argument is particularly strong if monument dedications at Antietam and Carman's completed manuscript at Antietam are deconstructed. The manuscript depicts a reconciled nation that is proud of the bravery of all its Civil War veterans and speeches given at monument dedications convey the notion of a nation ready to emerge on the international stage with a dominant military and eagerness for a democratic empire. This was best demonstrated by the culture surrounding the Spanish American War, which actually was viewed by Americans as "recuperating the heroism of an earlier generation ... and healing the wounds and divisiveness" of the Civil War. ${ }^{15}$ The Spanish American War restored the manhood of the United States and served as a final "road to reunion. ${ }^{\prime 16}$ Ezra Carman was working within this culture and his finished product is representative of this. Furthermore, the tone and methods implemented by Carman were

\footnotetext{
${ }_{16}^{15}$ Amy Kaplan, Cultures of United States Imperialism, (Duke University Press, 1993), 219.

${ }^{16}$ Ibid.
} 
almost wholly adopted by the U.S. government in the 1920 s to commemorate American exploits in the Great War. These observations can make Civil War memory applicable on an even broader scale than the historiography currently demonstrates by opening up comparative opportunities between Civil War remembrance and subsequent U.S. military remembrance. 


\section{Chapter 2: The Historical Process}

Exactly forty-years after the battle of Antietam, General Ezra Ayers Carman stood on the field near the Dunker Church beneath the "beautiful blue sky of a perfect autumn day" before a large group of veterans from the Thirty-Forth New York State Volunteers and other spectators. He was employed by the War Department as Antietam's "Historical Expert", and present on behalf of Secretary of War Elihu Root to accept the Thirty Forth's large medieval looking monument. ${ }^{17}$ This monument dedication, like most others, was both a patriotic spectacle and emotional experience for all involved. Lieutenant L.N. Chapin, a veteran of the $34^{\text {th }}$ Regiment, wrote a detailed narrative of their monument's dedication that gives a complete impression of the symbolic event. As a whole, the ceremony truly took on melodramatic characteristics. Chapin described the faces of many "comrades being bathed in tears" upon viewing the field for the first time since the battle. ${ }^{18}$ After a business meeting in the Dunker Church, the aging veterans headed to their monument on Confederate Avenue and took an opportunity to recapture their youth by marching as soldiers: being "led by the band [they] found that they had not forgotten how to keep step, [they] touched elbows, and guided right." ${ }^{19}$ Lieutenant Chapin viewed the entire experience as being extremely spiritual. He felt "old familiar hands reaching down out, of infinite spaces, to clasp his own" and "heard old familiar voices calling out to him, out of the unseen." 20

\footnotetext{
${ }^{17}$ L.N. Chapin, A brief history of the Thirty-fourth regiment, N. Y. S. V: Embracing a Complete Roster of all Officers and Men and a Full Account of the Dedication of the Monument on the Battlefield of Antietam September 17, 1902 (Veterans Association of the Thirty-Forth Regiment Volunteer Infantry, State of New York, 1902),159.

${ }^{18}$ Ibid.,158.

${ }^{19}$ Ibid.

${ }^{20}$ Ibid., 156.
} 
As Carman stood before the veterans to accept their monument and give remarks, he too embraced the chance for an emotional outlet. He praised the uniqueness and importance of the battle he took part in and studied, labeling it as the "greatest and most momentous one" of the war. ${ }^{21}$ He credited Union victory at Antietam for ushering in the greatest achievements of the Civil War: "Here was made history, here was rolled back the first confederate invasion of the North; on this field was arrested the recognition of the Southern Confederacy and foreign intervention; on this field died human slavery." ${ }^{22}$ Carman viewed this battle as the pivotal moment in American history. He made sure that the men of the Thirty-Forth New York felt pride in their part by praising their "manhood and courage" and focusing on the fact that they were in "a most exposed position," came onto the field during "a most critical moment," and "contributed their full and generous share" to the victory. ${ }^{23}$ Carman credited the area in which the men of the $34^{\text {th }}$ fought, which happened to be the same part of the battlefield he fought for as commander of the Thirteenth New Jersey, as being the piece of the American continent most drenched in human blood. ${ }^{24}$

When the veterans boarded the train back to New York at day's end many would claim that the dedication was "the happiest, the sweetest, and the most sacred, of all their lives." 25 They left with affirmation that the memory of their fallen comrades would be perpetuated by their monument and that the legacy of their contributions to the war would not be forgotten. General Carman's work on the Antietam Board was largely responsible for allowing veterans to have these cathartic moments. This dedication serves as a microcosm of his work on the

\footnotetext{
${ }^{21}$ Ibid., 179.

${ }^{22}$ Ibid., 181-182.

${ }^{23}$ Ibid., 180.

24 Ibid.

${ }^{25}$ Ibid., 159.
} 
Antietam Board. It shows the kind of legacy that Carman felt Antietam should have in American history, but also shows the historical silences that the government would want in the field markers, maps, and battle narrative that Carman would create as the official word.

The year 1890 is the moment in which a "Golden Age of Battlefield Preservation" began. $^{26}$ In this year the initiative was launched to establish America's first five military parks, and Antietam was among them. The War Department chose to make Antietam a national battlefield in 1890 and expanded the Cemetery Association into an "Antietam Board" that would be responsible for marking the field of battle. Fifteen-thousand dollars were allocated to accomplish this goal. Although Carman was not a part of this initial establishment, the Board's original directives would be the same ones he followed. It is of the utmost importance that these directives be understood because like all government historians, Carman was bound by his employer's wishes.

In the government's view, interpretation of Antietam was to specifically focus on "American heroism and constancy." 27 These traits were believed to have been definitively displayed at Antietam because the battle took place before "either of the contending armies had learned the protection to be afforded by the use of breastworks." ${ }^{28}$ Antietam represented the bygone days of warfare, a period in which military heroism had been preserved from the complexities of modern technology. Thus, "grand tactics" were to be the main thrust of the board's commemorative efforts. ${ }^{29}$ It was believed that these would be the best "monuments of

\footnotetext{
${ }^{26}$ Timothy B. Smith, The Golden Age of Battlefield Preservation: The Decade of the 1890s and the Establishment of America's First Five Military Parks (The University of Tennessee Press, 2008), xvii.

27 "Quartermaster General, General R.N Batchelder to Antietam Board members Colonel J.C. Stearns and General H. Heth," January 18, 1892. Taken from the National Archives (NARA), RG 94 "Antietam Studies" (AS)

${ }^{28}$ Ibid.

${ }^{29}$ Ibid.
} 
the skill of the American soldier," whether he was a Yankee from the Army of the Potomac or a Rebel from the Army of Northern Virginia. ${ }^{30}$

The language used in the Antietam Board's directive clearly stated that the military interpretation presented would be one of a united country forged in heroic warfare. The fact that the battle led to one of the most revolutionary actions of the war, emancipation, was not even mentioned in the mission of the Board. Historians like David Blight have criticized the government for binding the interpretation of battlefields in a purely militaristic arena, saying that by doing this they were essentially moving away from racial advancements made during Reconstruction. ${ }^{31}$ This criticism is warranted, yet it is difficult to see how an endeavor focusing on cultural tensions could produce representations of one America, and definition of what it meant to be American. Emancipation would be silenced out of necessity to achieve the government's goals. In Carman's history of Antietam he primarily framed emancipation as a controversial decision. He spoke regularly of McClellan's open declaration against Lincoln's policy and reported that "every one of [McClellan's] corps commanders were opposed to the administration, and that two-thirds of the division and brigade commanders were of the same view." $^{32}$

Expecting progressive interpretations of divisive cultural issues surrounding a battlefield in the 1890 s is unrealistic; this kind of interpretation rarely even happens in the present. The battlefields produced in 1890s were a product of their times that aided in the country's move toward reconciliation. Preservation of the military part of the battlefield was a very narrow

\footnotetext{
30 Ibid.

${ }^{31}$ Smith, The Golden Age, xvii.

${ }^{32}$ E.A. Carman, The Maryland Campaign of 1862 (Routledge Press, 2008), 79. Pierro, ed.
} 
objective, but it at least allowed sacred pieces of American soil to be preserved so that future generations could stand upon them and initiate the cultural debates that individuals in 1890 would not yet broach. The strong words spoken at the Thirty-Forth New York monument that were cited at the beginning of this section demonstrate that immediately after the formation of the battlefield this kind of phenomenon was already happening. Groups were using the battlefield in their own unique ways and perpetuating a message other than that given by the government. Even the government historian working to create the official narrative saw that in certain circumstances he could step out of the framework, which he loyally upheld, and speak of the deeper meanings of his contributions at Antietam. He did this by telling veterans during a dedication that "from the beginning of the war earnest and patriotic men and women, recognizing that slavery was a curse to the country and the cause of the war, prayed and urged that the institution be destroyed." 33 It seems rather obvious that Carman considered himself to be one of these patriotic individuals, yet in his history barely any of this interpretation comes through. Emancipation in his history was something that simply happened, and begrudgingly at that.

The inherent difficulties that would be faced in accurately marking Antietam Battlefield and providing interpretation of the battle were acknowledged from the very beginning of the Board. In general it was observed that there was an "absence of reports in many cases from officers" regarding Antietam. ${ }^{34}$ As a result "extensive correspondence with survivors of the several organizations that participated in the engagement" would become necessary for the

\footnotetext{
${ }^{33}$ L.N. Chapin, A brief history of the Thirty-fourth regiment, N. Y. S. V:, "Carman's Remarks."

34 "Quartermaster General, General R.N Batchelder to Antietam Board members Colonel J.C. Stearns and General H. Heth," January 18, 1892. NARA, RG 94 (AS).
} 
board's objectives to be completed. It was understood that questions of accuracy could be raised due to "natural influences of twenty-nine years" that might have worked on veterans' memories. ${ }^{35}$ Carman immediately offered his expertise to the board and sought to be a part of this mission. He was recommended by Louis McComas (former Maryland Congressman and main proponent of Antietam Battlefield) and Representative William Cogswell (R. Massachusetts), as being "specially fitted for the duties which would devolve upon him." ${ }^{36}$ Secretary of War Redfield Proctor denied Carman the job, however, because questions arose about him holding an unfulfilled government contract in the past. ${ }^{37}$ In response to the charges Carman revealed his commitment to country bluntly asserting that "I never had a contract of any kind with the government and I challenge any man to produce it, except a contract I made in 1861 to help put down the rebellion, which I faithfully kept.." ${ }^{38}$ This defense, along with a change of leadership in the War Department to Secretary of War Charles Lamont, cleared the skepticism surrounding his name. Still, Carman's first attempt to get on the Board was rejected.

It was not until 1894, after the Board had faltered under the leadership of former Confederate General Henry Heth for three years that Carman was finally appointed by the War Department to serve as the historical expert of the Antietam Board to aid in the creation of the official history of the battle. ${ }^{39}$ He was at last able to return to the project he began thirty-two years previously. This assignment would compel Carman to fully embrace the establishment of a national conversation with veterans. With the government's directives in hand Carman

\footnotetext{
${ }^{35}$ Ibid.

36“" Louis McComas to the Secretary of War," June 11, 1891. NARA, RG 94 (AS).

${ }^{37}$ Smith, The Golden Age, 90.

38 "E.A. Carman to Hon. Louis E. McComas," July 4, 1891. NARA, RG 94 (AS).

${ }^{39}$ Heth was not removed from the Board, he remained the Confederate representative because it was apparently thought that some veterans would feel more comfortable dealing with a veteran from their cause.
} 
worked within a scaffold in which he could provide veterans' memories focus. Other's

memories would oblige him to revisit his own and decide what interpretation of the battle of

Antietam would be forged on both iron tablets across the battlefield and in an historical

manuscript. His work on this project established him as the preeminent "Antietam Expert," and

much of the history he produced is still considered the official word and standard to which

contemporary work must be measured.

Carman's primary means of initiating a discussion with veterans regarding their memory

came from a simple form letter. This letter began by acknowledging that there were gaps

present in the historical facts of Antietam and that the Board found "it necessary to call upon

the knowledge and kindly assistance of surviving participants. ${ }^{\prime 40}$ This humble opening was

likely an effort to show veterans of both the Union and Confederate armies that their memories

would be treated equally. ${ }^{41}$ Included with the letter was a small map of the portion of the

field on which the chosen veteran had fought. With this map they were to "mark [their] route

to the front, subsequent movements on the field, bivouac," and units around them. ${ }^{42}$ Once

this was done, Carman afforded the veteran an open ended option. They could then include

any "explanatory remarks as may be necessary to give a clear understanding of the part taken

in the action by [their] regiment or brigade." ${ }^{43}$

${ }^{40}$ Ezra A. Carman, "Antietam Battlefield Commission War Department (form letter)," July 13, 1895. Taken from Antietam Archives (AA), Sharpsburg, Maryland. The form letter used by Henry Heth was nearly identical to Carman's, however, this does not lessen the connection of Carman to the Antietam discourse. Carman's scholarly production far surpassed Heth's so his choice to continue with a similar form letter demonstrates that he wanted military/tactical memories coming in to him.

${ }^{41}$ The contemporary expert on Carman, Tom Clemens, has described Carman's neutrality as follows: "He avoided terms that could cause hostility and seemed to be on good terms with his former enemies. The Confederate accounts in Carman's papers indicate that they respected Carman and appreciated his task." Ezra A. Carman, The Maryland Campaign of September, Vol. I South Mountain (New York: Savas Beatie, 2010), xvi. Clemens, ed.

${ }^{42}$ Carman, "Form Letter," 13 July 85. (AA).

${ }^{43} \mathrm{Ibid}$. 
This form letter is an extremely short piece of correspondence, yet much can be drawn from it. Carman clearly implemented a courteous tone in the document that would be approachable to all veterans. He also made an attempt to limit the correspondence to what experiences the veteran had within the boundaries of a small map. This gave direction to the veterans' memory and would hopefully yield more accurate returns. It forced a focus on one event and skirted controversial social issues that can often overpower the more basic meanings. Even when Carman loosened the bridle and allowed veterans' minds to wander, he attempted to limit the detour to "their [emphasis added] regiment and brigade." ${ }^{44}$ He did not want long tomes coming in that emotionally expressed motives for fighting, but instead desired tactical memories to create a military history. All veterans of the battle shared in this and would be on equal footing when recollecting. If parts of the correspondence were deemed usable to Carman, or if they raised larger questions that he needed to answer, they would remain open for as many exchanges as necessary.

The structure and content of the form letter is revealing about the way Carman chose to guide veterans' memories, but it also highlights one of the major weaknesses of the archival evidence left by Carman. Very little of Carman's voice is present in the correspondence. There are thousands of veteran letters preserved in archives, but most of the correspondence is one way. Many of the letters are simply responses to questions from Carman that are not available anymore. The overwhelming sameness of responses leads to a belief that the form letter was basically followed by Carman, yet there still had to be slight alterations.

\footnotetext{
44 Ibid.
} 
The sterility of the form letter does not reveal much of a human touch, but evidence shows that Carman often did try to please as many veterans as he could and worked to foster amicable relationships. In many instances Carman would alter his personal schedule and travel itinerary to meet with veterans on the battlefield in order for them to personally show him where they were located on the field and what movements they made. In a letter from David Johnston, a veteran of the $24^{\text {th }}$ Virginia Regiment, living in Bluefield, West Virginia, Johnston proposed that Carman delay an upcoming trip to Antietam for a couple days so that Johnston and another comrade could arrive at the same time. Carman obliged, and within a week Johnston was back at home in Bluefield writing to Carman in an attempt to clarify some inaccurate statements that he made out of excitement on the field. ${ }^{45}$ Other letters reveal that Carman sometimes provided veterans with keepsakes from the battlefield during their visits. After Carman opened up a line of correspondence with Confederate veteran J.T. Brown that had been closed for some time, Brown began the new exchange with thanks: "Your favor of the $2^{\text {nd }}$ received, and called to memory the most pleasant trip I had with you two years ago and the handsome and very appreciated present of a walking cane cut from the timber near the Dunkard Church." 46

In a letter to one of Carman's Union friends who was involved with the discovery of General Lee's lost order "No. 191" he allowed a rare look into his personal feeling toward the battlefield and the compassion he had toward his former comrades. In this particular piece of correspondence Carman was somewhat reminiscent, closing his letter as follows:

\footnotetext{
45 “Johnston to Carman," 24 September 1897 and 4 October 1897. NARA, RG 94 (AS). Reel 2, 86-87.

46 “Brown to Carman," 6 August, 1898. NARA, RG 94 (AS). Reel 1, 757.
} 
How is the world using you? As time goes on I see less and less of the old comrades and they gradually drop out of sight. Whenever you come this way, inquire for me at the War Dept. Washington, where I am generally to be found, barring a few weeks in the summer, when I am on the old glory field. ${ }^{47}$

It is quite clear from this that Carman cherished the time that he was able to have on the "old glory field." Antietam was a part of him and he wanted to share it with as many veterans who shared the same sensibility as he did. It seems that the aging and death of his generation wore heavily on his mind.

Carman also showed respect for the dead of Antietam, regardless of the side they fought for. This is evident from his handling of the accidental discovery of six unknown Confederate soldiers during excavations near the Dunker Church woods in 1896. Carman quickly had the men placed in boxes and contacted General H. Douglas, who held charge of the Confederate burial plot in the Hagerstown Cemetery, about re-interment. If this was not desired Carman assured Douglas that he would see that "we shall promptly re-inter them on the spot where they have rested for thirty four years past." ${ }^{48}$ Although relationships cannot be built with deceased, acts like this held symbolic power and could have helped Confederate veterans trust Ezra Carman with their recollections.

The professionalism and passion that Carman showed towards veterans did not go unnoticed. Often after visits on the battlefield with Carman they would return to their homes and write their impressions of the historian in local newspapers. This was often done as an attempt to show other veterans that they could trust Carman with their memories and that he

\footnotetext{
47 "Carman to Colonel S.E. Pittman," 3 May 1897. Taken from Dr. Tom Clemens's blog The Maryland Campaign of September 1862, http://marylandcampaign.com/. Accessed on 29 January 2011. This blog was established to promote the upcoming publication of Dr. Clemens's two volume edited version of Ezra Carman's Antietam manuscript. The blog also houses an ever growing database of Carman correspondence letters.

48“ E.A. Carman to General H.K Douglas,” 12 September 1896, AA, (CC).
} 
was someone worth dealing with. In The Richmond Times as Confederate veteran wrote of

Carman that "he is an officer and a gentleman in the right place." ${ }^{49}$ Northern veterans similarly wrote that "he is a genial gentleman, thoroughly competent, a splendid specimen of well reserved manhood. . ${ }^{50}$ This kind of press could do nothing but aid Carman in his historical endeavors.

One of the most revealing mediums of Carman's historical process comes from his involvement in monument dedications. Looking at the way Carman handled the preparation for monument dedications offers insight into the work he did to create his narrative, markers, and maps of Antietam. The process was very arduous, involved, and required frequent contact with veterans. These types of projects were a large part of Ezra Carman's job as historical expert. A 1908 publication entitled Second Brigade of the Pennsylvania Reserves at Antietam chronicles the entire process that their commission went through to erect monuments on Antietam battlefield. ${ }^{51}$ At the end of this publication, all of the correspondence between Ezra Carman and the Pennsylvania commission working to erect the monuments were presented.

This correspondence demonstrates the hands on approach that Carman adopted when working with veterans to place their memorials on Antietam's hallowed ground.

Between October 1905 and September 1906, Carman regularly wrote the Pennsylvania commission and offered any help that he could to them. He sent maps to members of the commission marking positions of different units, arranged meetings between himself and the

\footnotetext{
49 John Connor Scully, Ezra Carman: Soldier and Historian (George Mason University: Master's Thesis, 1997$), 98$. Cited as, Richmond Times, 21 April 1895.

${ }^{50}$ Ibid. Cited as Martin County Tribune, August 17, 1895, article by Major William Houghton, $14^{\text {th }}$ Indiana.

${ }^{51}$ Albert Magilton, Second Brigade of the Pennsylvania Reserves at Antietam: Report of the Antietam Battlefield Memorial Commission of Pennsylvania and Ceremonies at the Dedication of the Monuments Erected by the Commonwealth of Pennsylvania to Mark the Position of Four Regiments of the Pennsylvania Reserves Engaged in the Battle (Harrisburg, PA: Harrisburg Publishing Company, State Printer, 1908).
} 
commission in Sharpsburg, and even drove stakes into the field identifying positions of Pennsylvania units. ${ }^{52}$ Additionally, Carman checked all of the proposed inscriptions on the monuments for historical accuracy, offered suggestions for revisions, provided information on the reliability of certain contractors, and kept the commission updated on progress of the monument's construction once work on it began. ${ }^{53}$ This type of work shows the capability of Carman as an administrator and his desire for Antietam Battlefield to be respected for a level of professionalism. Some aspects of the correspondence move beyond the thick administrative layer, however. They reveal Carman's desire to create a fulfilling experience for veterans, his affinity for hearing veterans' recollections, and the frustrations of an historian.

An efficient process for monument placement was not all that Carman cared about. He also valued the emotional aspect of it all. Evidence of this is his desire to make sure that Pennsylvania veterans coming to the monument dedications would have the same kind of sentimental experience that veterans of previous dedications had enjoyed. Having seen many "very successful" dedications, Carman suggested that when the Second Pennsylvania Brigade dedicated their monuments they "first had regimental ceremonies at each of the four monuments in the morning, and then a general ceremony in the early afternoon at the cemetery." ${ }^{154}$ This would heighten the meaningfulness of the sacred deed they were there to perform. He also wanted all of the veterans to "assemble and give their recollections." 55 This recommendation served a dual purpose; it would allow veterans to share their recollections and be a part of the pageantry, but could also help to clarify some inaccuracies that had been

\footnotetext{
52 Ibid., 90

${ }^{53}$ Ibid., 93.

${ }^{54}$ Ibid., 94.

${ }^{55}$ Ibid., 98.
} 
encountered trying to locate the exact locations that the Pennsylvania units' bivouacked at on the night preceding the battle. ${ }^{56}$

Carman's wish to have aging veterans stand up and give their recollections in an attempt to bring clarification to a contested fact is indicative of the way he worked on his Antietam history. He always wanted to engage veterans in some form of open conversation, whether it was through paper correspondence, battlefield tours, or even at a monument dedication. For some aspects of the battle of Antietam “the Official Reports [were] silent. . ."57 When this was the case, Carman was "compelled to rely upon the information furnished by survivors. . " ${ }^{58}$ Lone recollections offered only a marginal chance of being correct. If multiple memories of veterans came to Carman and showed a similarity he could take them as being closer to truth. Sometimes details were so "conflicting" that a definitive answer could not be given. ${ }^{59}$ Carman realized the limitations of this type of work, and instructively told one of the members of the Pennsylvania monument committee that "it would be very strange if you succeeded in pleasing everybody." ${ }^{60}$ It is likely that Carman reached acceptance of this fact very quickly into his work with the Antietam Board. Recollections from men at the ends of their lives were not always crisp and lucid. This was exacerbated by the fact that many of the interpretations coming to Carman were from former enemies. Under these extraordinary circumstances the chance of pleasing all parties involved was nearly nonexistent.

The relationship between Carman and veterans is important, but the larger implications of his work are what need to be given more careful attention. One of the most powerful

\footnotetext{
56 Ibid.

${ }^{57}$ lbid., 96.

58 Ibid.

59 Ibid., 98.

60 lbid., 99.
} 
aspects of Carman's position was the power he had to create a national conversation, and eventually a single narrative reflective of the entire country. The initial conversations between Carman and veterans responding to his questionnaire were very private in nature, but they often became very public exchanges. One of Carman's questionnaires sent out to Colonel Todd of the $35^{\text {th }}$ New York Volunteers went all the way across the country and reached three different veterans before it returned. Charles Sloat finally came in possession of the Carman inquiry and explained its journey as follows: "I am in receipt of a communication sent out by you on November 23, 1864 to Captain J.G. Todd asking for information about the action taken by the $35^{\text {th }}$ NY Vol. at the battle of Antietam in 1862. Capt. Todd, for some reason, sent the communication to Capt. L.F. Lyttle of Toledo, who sent it to me with the request that I furnish the information asked for." ${ }^{61}$ In the end, Sloat had little to offer Carman and conceded that "he knew so little of the matter and [that] so long a time has elapsed since the events of the day that I fear the impressions left with me will be of little value to you in ascertaining the true facts. . . ${ }^{\prime 2}$ This kind of episode was surely disappointing for Carman because of the limited return. Still, it demonstrated the way that veterans tried to work amongst each other to provide Carman truth.

A better example of a veteran using Carman's inquiry to work with comrades and come to consensus on events can be seen from secretary Thomas W. Bishop of the $21^{\text {st }}$ Regiment, New York Volunteers Veteran Association. As secretary of the $21^{\text {st }}$ Veteran Association, Bishop was given an inquiry sent by Carman to Captain George Baker and asked work within the veterans' organization to find answers. This process evidently took time, but did produce

\footnotetext{
61 "Sloat to Carman," 13 December 1894. NARA, RG 94 (AS). Reel 1, 180.

${ }^{62}$ Ibid.
} 
results. When Bishop responded to Carman he apologized for a "delay caused by necessary correspondence with scattered survivors. . ."63 Yet, "from careful comparison of different statements received" he was able to confidently produce a detailed four page account of the regiment's actions during the battle. This inquiry to a single veteran initiated conversation at a veterans' association meeting, and through correspondence. Ultimately it produced a usable memory that was a product of several participants in the battle. This was as close to truth as Carman's process could hope to get.

Many veterans wrote to Carman in acknowledgement that his work could produce truth. General R.R. Dawes actively participated in correspondence with Carman and historians working at Gettysburg to help aid in the preservation of his action on both battlefields. In a letter to General Carman he indicated that he understood exactly how Carman would have to handle correspondence for it to be of any use. Dawes indicated to Carman that immediately after he sent a response to his questions that he "made an error." ${ }^{64}$ The reason for the error was that "memory, which comes out of the fog of thirty-seven years cannot be fully depended upon. . ." ${ }^{65}$ Dawes believed that this was completely remediable though, due to Carman's historical methods. Carman was doing his work in a way that helped eliminate mistakes and check memories for accuracy. Dawes gave Carman assurance that he trusted him and that if his “statements are verified by independent facts within your [Carman's] knowledge; they can be accepted as correct." 66 This was a veteran who fully embraced the methods that Carman used

\footnotetext{
63 “Bishop to Carman," 21 January 1898. NARA, RG 94 (AS). Reel 1, 148.

${ }^{64}$ R.R. Dawes to E.A. Carman," 16 January 1899. . NARA, RG 94 (AS).

${ }^{65} \mathrm{Ibid}$.

${ }^{66}$ Ibid.
} 
and was comfortable to work with them. Carman's questions guided the way he remembered and provided a safety net if he faltered slightly.

Confederate veterans partook in side conversations as well, but often the tone of these discussions seemed more urgent or deliberate. They were very open about their desire for Southern bravery's placement in the official memory of Antietam. This explains the practicality of Carman's attempt to keep discussion focused on the military. The Southern agenda was especially evident in letters former Confederates were writing amongst themselves in preparation of standing before Carman's gateway. Lieutenant Colonel S.D. Thruston of the Army of Northern Virginia corresponded with a former comrade that his "interest in the history of the conduct of the self sacrificing men of the $3 \mathrm{~d}$. N.C. is too deep and fervent to do aught than put my shoulder to the wheel and help push forward the great car of truth and justice to those dead and living heroes." ${ }^{67}$ In similar correspondence Thruston had with comrades they would sanctify their old fraternity and close their letters "Yours truly in confederate bonds." ${ }^{68}$ The tone of these letters not surprisingly reveals that some veterans would not wholly embrace Carman's framework. Dissenting memory was a common occurrence in Carman's correspondence.

\footnotetext{
67 "S.D. Thruston to Colonel W.L. DeRosset," 5 August 1895, AA, (CC).

68 “D.H. Hill to S.D. Thruston," 12 June 1896, 12 June 1886, AA, (CC).
} 


\section{Chapter 3: Dissenting Memories}

In a letter from Carman to another historian of Antietam, Major John Gould of the Tenth Maine, he vented some aggravation about his laborious task. He confided in Gould that "out of 100 letters written I get replies to about 50 and of the 50 not more than 4 or 5 are of any value. It takes more trouble to eliminate myths than to get solid fact." ${ }^{69}$ In the end he concluded that "the whole field is as full of hard nuts as those you have found on the East Woods." ${ }^{70}$ To many historians this kind of statement should not seem foreign, extensive research and writing can be an exhausting and frustrating experience. This is particularly true when much of your research is based on interaction with living historical actors and their memories. Based on the overwhelming evidence of Carman's attachment to Antietam and respect for veterans, this kind of comment cannot define Carman's work with veterans' memories. It is more likely just release of frustration that only another historian could understand. Still, it accurately sets the stage for dissenting memories and Carman's shelving of them. It also makes present scholars ponder if the silenced dissent is the most valuable remnant of Carman's correspondence. In many cases dissenters from Carman's framework seemed to be providing the most realistic and vivid accounts of Antietam.

Carman's efforts to keep memories in the controlled realm of tactics and valor were not always successful. For some veterans adhering to Carman's well defined vision was undesirable. Corporal Lewis Reed of the Twelfth Massachusetts Infantry had experienced too much at Antietam to contain his memory within Carman's questionnaire. He felt "like not

\footnotetext{
${ }^{69}$ Scully, Carman, 102. Cited as 28 May 1898, letter from Carman to Gould, Antietam Collection, Dartmouth College Library.

${ }^{70}$ Ibid.
} 
writing at all" of Carman's tactical questions because they had already been thoroughly presented by others. ${ }^{71}$ Reed instead used the correspondence as a means to recreate a personal narrative of the chaos he experienced. He talked of seeing men fall wounded around him, including his tent mate who fell beside him to never rise again. He graphically described being wounded in the neck, laying on the ground in a state of confusion, and realizing that "his shirt and blouse [were] filled with blood." ${ }^{\prime 72}$ After this discovery he and seriously thought that "it was his last day on earth." Tactics were not on his mind then, nor were they as he wrote to Carman thirty-two years later. What was on his mind were "feelings of home and friends and thousands of other thoughts." ${ }^{\prime 73}$ Reed's letter shows a soldier not willing to tailor his memory to Carman's discourse, but speaking about what mattered to him personally. Nevertheless, it was still Carman's questioning that opened up the gates and allowed this memory to come through and provide a tangible memory of September 17, 1862. Although compelling, it was unusable to Carman because it did not fit into the specific mission he had undertaken on behalf of the War Department.

A similar moment of sullen reflection came through in a letter from W.H. Walling, a veteran of the $16^{\text {th }}$ New York Volunteers. In this line of correspondence Carman was interested in locating the right flank of the Walling's unit. This particular question brought forth a flood of emotions from Walling. He proclaimed that "This position is most vividly and most thoroughly impressed upon my mind because it was sealed with the blood of Corporal Smith, a cousin of

\footnotetext{
71 “Corporal Lewis Reed to Ezra Carman," 13 April 1894. Taken from Dr. Tom Clemens's blog The Maryland Campaign of September 1862, http://marylandcampaign.com/. Accessed on 18 April 2010. This blog was established to promote the upcoming publication of Dr. Clemens's two volume edited version of Ezra Carman's Antietam manuscript. The blog also houses an ever growing database of Carman correspondence letters. ${ }^{72}$ Ibid.

${ }^{73}$ Ibid.
} 
mine." ${ }^{74}$ The two men had grown up together, gone to war together, and fought in the same unit. In fact, Corporal Smith's parents had taken in Walling as a youth when his parents' death left him an orphan. On the day after the battle, Walling engaged in conversation with his cousin. They lay on the ground face to face supporting their heads on their hands with elbows as a base. In the midst of their talk a Rebel bullet passed under Walling's arm and "crushed through his [cousin's] body with a thud." ${ }^{175}$ Walling's cousin was immediately taken to the right flank and placed beside a haystack where he died. This traumatic incident burned the location into Walling's mind and gave him confidence that "he could see the contour of the ground as plainly today as in the day of the battle," in the letter his memory seemed to be irrationally telling him that after several decades the same bale of hay would rest where it did back then. ${ }^{76}$ The death of cousin Smith was of no use to Carman and the haystack that marked the flank that Walling remembered was long gone. Still, the tactical question ushered in a vivid memory that would otherwise never have been captured for future scholars of Antietam, or the Civil War.

Some memories of Antietam that came to Carman did not focus on the actual battle at all, but the unimaginable conditions of the battlefield in the following days. One veteran of the $124^{\text {th }}$ Pennsylvania Infantry revealed to Carman that the most lasting memory burned into his consciousness regarding the battle was his assignment to bury Confederate dead. He felt the need to explain this job to Carman in great detail, remembering that "if a person is not killed out right he turns on his back to die \& such was the case with most of these dead. Fermentation of the stomach had set in, and blubbers at the mouth were breaking all around

\footnotetext{
74 “Walling to Carman," No Date. NARA, RG 94 (AS). Reel 1, 542.

${ }^{75}$ Ibid.

${ }^{76}$ Ibid.
} 
you, making a slight noise in the breaking, giving a queer weird feeling to many a person as one moved about among the dead." ${ }^{77}$ This graphic description certainly was never used by Carman in his manuscript on Antietam, but it describes an episode at Antietam that has the ability to reach visitors to the battlefield in a way that tactical memory never could.

Episodes of graphic violence and emotional pain were not the only memories that Carman's questioning initiated that were not of much use to him. As many veterans began to relive their movements on the battlefield, memory brought back episodes of great entertainment. Colonel James H. Lane of A.P. Hills Division felt compelled to relay to Carman an amusing story that his runner told to him during the height of the battle upon returning from John Pender's Brigade:

He [my runner] laughingly told me of an amusing incident he saw when returning in the rear of Pender's brigade, which was lying behind a stone fence. A Federal cannonball ploughed a hole in the ground just in the rear of the line, and a Tar Heel stretched himself in the hole with the remark it was the safest place for him as no two shots ever struck in the same place. The next ball came very near taking his head off, and he sprang back to the fence with a very emphatically expressed disbelief in the old saying much to the merriment of his comrades. ${ }^{78}$

This incident was the bulk of Lane's response to Carman in this letter. It is noteworthy that light hearted recollections like this one were able to emerge decades after the fact.

A similar humorous episode was told by A.C. Haskell of McIntosh's South Carolina Artillery. In locating the position of McIntosh's artillery on a map to Carman, Haskell's memory focused on the antics of a Union soldier in Burnside's division. During a heated contest one of McIntosh's guns was captured by Burnside's men and one of the Yankee conquerors “jumped

\footnotetext{
77 “Charles Broomhall,” 29 June 1891. Taken from H.Net, Memories of America's Bloodiest Day: A veteran of Antietam spent his life collecting accounts of the war's most horrific fighting. Accessed 31 January 2011. This was an article written by prominent Antietam scholar Tom Clemens that shared several of Carman's letters and promoted the upcoming release of his edited treatment of Carman's manuscript.

78 "James H. Lane to E.A. Carman," No Date. NARA, RG 94 (AS). Reel 2, 489.
} 
on the cannon and flapped his arms and crowed" to the Rebels. ${ }^{79}$ This act only angered the Confederates who had just been driven back and enticed them to reform quickly because the antic was only adding "insult to injury." 80 In all of Carman's analysis of Mclntosh's artillery no mention of Burnside's crowing soldier ever is made.

Gore and humor were not the only forms of dissent that Carman faced. Heated debate would often be initiated with his correspondence to veterans. Evidence of this is a collection of letters that he kept as memoranda files that would be used as he worked on his history. In this correspondence several Confederates exchanged passionate words about labels of cowardice that were leveled at the Third North Carolina Infantry Regiment at the Battle of South Mountain. In these letters the $3^{\text {rd }}$ N.C.'s commander, Colonel W.L. De Rosset wrote to his old division commander, General D.H. Hill, to make it known that their brigade commander, General Ripley, held them back in the battle and kept them from being the brave men that they wanted to be. De Rosset felt that although Hill had "spoken of our [ $\left.3^{\text {rd }} \mathrm{NC}\right]$ conduct at Sharpsburg, he has not done us justice." ${ }^{81}$ To remedy this, De Rosset took it upon himself to write to Hill in an effort to alter his perceptions and vilify Ripley as a brigade commander. In the end it had the desired effect. Hill wrote to De Rosset that he had read his letters of explanation carefully. ${ }^{82}$ De Rosset was able to turn Hill completely against Ripley. Hill wrote that he had "feared that he [Ripley] was either a coward or a traitor" because he was a "Yankee by birth." ${ }^{83}$ Had Hill known Ripley's true character at the time of South Mountain he would not

\footnotetext{
79 “A.C. Haskell to E.A. Carman,” 13 January 1897. NARA, RG 94 (AS). Reel 2, 557.

80 Ibid.

81 “De Rosset to Thruston," 1 June 1886. NARA, RG 94 (AS). Reel 2, 739.

82 “ Hill to De Rosset," 22 June 1885. NARA, RG 94 (AS). Reel 2, 735.

${ }^{83}$ Ibid.
} 
have placed him on the right flank because "he could hide himself finely" there. ${ }^{84}$ Instead he would have "placed him on the left where he could be seen," perhaps then "the day might have been saved." 85

This exercise was very therapeutic for De Rosset and he indicated such to a comrade. Apparently De Rosset's memory of South Mountain had haunted him for many years. He wrote that he needed to confess "that I left that field with my head hung in shame at not having been given the opportunity to aid our brave comrades. To Ripley be all the blame and shame," ${ }^{86} \mathrm{He}$ then made his attack on Ripley more personal, wishing that his superior had "received a deathwound" in the engagement. ${ }^{87}$ Even after releasing all of this anger De Rosset still felt that Hill had not altered his impression of the $3^{\text {rd }} \mathrm{NC}$ enough. He urged his comrades to write their own letters to Hill asking for them to condemn Ripley themselves and for Hill to write a letter in a public forum explicitly blaming Ripley for holding back the $3^{\text {rd }}{ }^{88}$ Personal attacks were not particularly useful to Carman, but some of this heated correspondence made its way into his finished narrative. De Rosset 's view became the official word, Carman described Ripley at South Mountain as follows: "Ripley, who had been left by D.H. Hill in command of four brigades, appears to have been unequal or disinclined to the task." 89 De Rosset was able to leverage his memory and will it into the definitive history.

A great deal of dissent also came to Carman from Confederates with regards the final outcome of the battle. This kind of dissent proves to have affected Carman a great deal. He

\footnotetext{
${ }^{84} \mathrm{Ibid}$.

${ }^{85} \mathrm{Ibid}$.

86 “De Rosset to Thruston," 1 June 1886. NARA, RG 94 (AS). Reel 2, 739

${ }^{87} \mathrm{lbid}$.

${ }^{88} \mathrm{Ibid}$.

${ }^{89}$ Carman, The Maryland Campaign, 153. Pierro, ed.
} 
received many letters contesting the belief that Antietam should even be considered a Union victory. One veteran vehemently urged that Carman view the battle as a draw, writing "it is the fortune of battle, that in a hardly contested action in the open field each side advances and falls back, unless something decisive occurs. Every thoughtful person must realize that Antietam or Sharpsburg battle was a drawn battle." ${ }^{90}$ In the end he warned Carman that "to claim (we mean for either side to claim) that they permanently occupied the ground they fought over is union unwise, because untrue. ${ }^{91}$ This interpretation offers an excellent example the inherent silences that a tactical focus created for the overall memory of the Civil War. The veteran cared only about the tactical interpretations of the battle in his consideration toward a victor. He gave no mention to the devastating consequences that the battle had on the Confederacy. Lincoln's decision to issue the Emancipation Proclamation, officially turning the war towards racial goals was not important, nor was the South's lost opportunity to gain foreign recognition. These political issues were unimportant to the military interpretation and did not highlight the valor of the soldier, and for a message of nationalism to come forth this would have to remain the case. Another veteran took this interpretation a step farther and dismissed the notion of a draw or a Union victory. He bluntly told Carman that "It was not a victory for General McClellan, he had attacked an army scarcely more than one third as strong as his own and was repulsed with a loss one third greater than that experienced by his antagonist." ${ }^{92}$

Confederate veteran James Garret wrote Carman from the University of Virginia in 1895 to tell his actions in the battle and to plead that Carman create a history favorable to the South.

\footnotetext{
90 Y.J. Pope to E.A. Carman," 20 March 1895, AA, (CC).

91 "Y.J. Pope to E.A. Carman," 20 March 1895, AA, (CC).

92 "J.M. Day to E.A. Carman," No Date. NARA, RG 94 (AS). Reel 2, 637.
} 
Garret had recently read a history of Antietam that grossly increased the numbers of Lee's force at Antietam to $97,445 .{ }^{93}$ Garret wanted to know how figures like that could be put forth as "the truth of history" and urged that Carman not continue this pattern of "teaching the rising generation the untruth of history" with his own work. ${ }^{94}$ He ultimately felt dejected and helpless, writing that "we [Confederates] must depend of truth-loving Federal writers." 95 Carman did not entirely share the interpretation of a stalemate or Union loss, but surprisingly in his chapter of The Maryland Campaign dealing with the campaign's results he was not as far away from this as one might think. In Carman's view the result of the Maryland Campaign was satisfactory neither to the North nor the South." ${ }^{\prime 96}$ Carman's interpretation left serious omissions that should have been filled with the radical turn in the war that was made possible by Union victory at Antietam. In Carman's final view the North was disappointed in the loss of Harpers Ferry and failure to follow Lee's army and destroy it. The South's main disappointments were that Marylanders did not rally to the Southern cause and that the main battle was drawn. ${ }^{97}$ Carman did not go into analysis of Lincoln's decision to issue the Emancipation Proclamation following the battle. He handled the issue by quoting that Lincoln made a "solemn vow to God that if Lee was driven back he would issue the proclamation." ${ }^{98}$ By the time Carman needed to pen the official history his tactical framework and government assignment had saturated and altered his own mindset.

\footnotetext{
93 “James Garret to E.A. Carman," 25 February 1895. NARA, RG 94 (AS). Reel 2, 603.

${ }^{94}$ Ibid.

${ }^{95}$ Ibid.

${ }^{96}$ Carman, The Maryland Campaign, 378. Pierro edition.

${ }^{97}$ Ibid.

${ }^{98}$ Ibid., 379.
} 
The will of the dissenters sometimes came through, and even if it did not their memories stand out as gems among the majority of conforming memories. Dissenting memories that refused to enter into the scaffolding that the government had erected for them are a guidepost for modern historians looking for silences and true representations of the Civil War. As demonstrated, some of the dissent found its way into Carman's history, but the vast majority of them remained in the ether. The dissenting memories often tell the true story of war. They are stories of death, sorrow, shaken wills, and gore. These stories were silenced and replaced by conforming ones. The conforming memories were the ones that predominately found their way into Carman's history. 


\section{Chapter 4: A National Narrative and Conforming Memories}

Carman's historical work culminated with the writing of his manuscript, The Maryland Campaign of 1862. Carman died before his work could be published and his handwritten draft ended up finding a solitary home in the Library of Congress for several decades. Only the dedicated researcher could view Carman's final word and struggle reading his compact and sometime illegible penmanship. It became clear very quickly that historians who read Carman's work respected its usefulness. Presently there are two edited publications of Carman's manuscript, and now anyone can easily access Carman's work. This manuscript is the culmination of all the research he undertook regarding Antietam, and in a way it can be considered Carman's side of the correspondence with veterans. The manuscript represents a national narrative that was aided by conforming memories of participants. Furthermore, it would help readers conform their own memories of the Civil War and Antietam to what was written.

It is somewhat enigmatic that before Carman began his discussion of the fighting at Antietam he chose to quote Francis Palfrey's 1882 description of Civil War combat and the inherent issues it created for the historian: "Orderly advances of bodies of men may be easily described and easily imagined, but pictures of real fighting are and must be imperfect.

Participants in real fighting know how limited and fragmentary and confused their recollections of work after it became hot. The larger the force engaged, the more impossible it is to give an accurate representation of its experiences." ${ }^{99}$ Carman and those he corresponded with had lived the chaos of Antietam and were aware that Palfrey was correct, yet few embraced this

\footnotetext{
${ }^{99}$ Carman, The Maryland Campaign, 214. Taken from Francis Winthrop Palfrey, The Antietam and Fredericksburg, vol. 5 of The Army in the Civil War (New York: Charles Scribner's Sons, 1882), 166.
} 
almost post-modernist belief that their memories were 'fragmentary' or 'confused.' Perhaps it was empowering for Carman and other veterans to acknowledge the chaos and then demonstrate that they could take it by the reins. Or maybe Carman was so confident in his methods that he felt readers would ultimately dismiss Palfrey's interpretation because of the good order that he gave the battle on paper. When Carman wrote, the clouds of smoke and shrills of wounded men were lifted and replaced with a battle that was absolutely ordered. His narrative neatly emplotted the battle into a series of several engagements and brought clarity to the fighting completely unobtainable in reality. For a text to instill feelings of pride in Americans this would have to be true. Other military historians would follow Carman's style and structure in the future.

It is very evident that as Carman wrote his manuscript he stuck closely with the original directives that the War Department gave the Antietam Board. He focused purely on the tactical, silenced dissenting stories, and told a story of American military capability. He even devoted a small chapter of his manuscript to describe the field on Antietam and attributed it as having characteristics that exemplified bravery and intelligence. The field was completely unique and he explained that "there was probably no battlefield of the Civil War more free and open to the movement of troops and the oversight of commanders." ${ }^{100}$ He also concluded that there was no other battle in which "more time was allowed for preparation, and none where the result depended so little on accidental circumstances." ${ }^{101}$ In short, the field dictated that the events of the battle directly hinged on "the ability of the generals and the conduct of

\footnotetext{
${ }^{100}$ Carman, The Maryland Campaign, 199. Pierro, ed.

101 Ibid.
} 
troops." ${ }^{102}$ Participants of this battle had experienced something unique to the Civil War. They were a part of a pristine battle that was not tainted by technological advances, but was fueled by the bravery and ability of the American citizen soldier. Americans could look at this battle and see an event in their past that they could be proud of.

Examples of this type of memory are abundant and their specific focuses are vast. One Union soldier from General Harstuff's brigade specifically recalled to Carman the beauty of well ordered soldiers. His greatest memory of the battle was pride in how beautifully his brigade moved into battle. He recollected that "In the early morning we moved out of the woods and across an open space in line of battle and it was a beauty; the brigade moved as one man as if on parade. I was proud of Harstuff's Brigade then, and lapse of years had not lessened by enthusiasm, nor convinced me that it was other than the peer of any brigade organization of the Army of the Potomac." ${ }^{103}$ Another Union soldier, H.C. Hoffman's, memory focused on the "perfect order" that his unit showed as they withdrew from the field after being overwhelmed by Confederate artillery. His sharpest memory of the day was overhearing Brigadier General Howard use their ordered retreat as an example to other men who were frantically trying to get out of harm's way. Hoffman described the event to Carman proudly, "That brave officer pointed to us as an example for the disorganized, saying as he did so, 'Men! That is the way to leave a field. That Regiment are acting like soldiers. Do as they do men, and we will drive them back again in ten minutes.'”104 This account found its way into Carman's history. Carman uses the exact quote that Hoffman cited from Howard and comments on Hoffman's men as "retiring

\footnotetext{
102 Ibid.

103 J. Huduckson [sp.] to E.A. Carman," 6 December 1894. . NARA, RG 94 (AS). Reel 1, 288-89.

104 "H.C. Hoffman to E.A. Carman [written in Carman's handwriting]", No Date. NARA, RG 94 (AS). Reel 1, $171-72$.
} 
in such perfect order to attract the attention" of their commander. ${ }^{105}$ Although both soldiers were concerned about very different parts of the battle, their memory was bound to the ordered way their respective units behaved. They both demonstrated to Carman that they were able to control the chaos of the battlefield. One bravely marched onto the field and one bravely walked off.

For these heroic and beautiful episodes to have validity to readers the soldiers participating in the battle had to be of the highest quality. Carman gave them this interpretation. The men who fought at Antietam were "Americans of all classes," and professions who "were the very best of the country." 106 It was also of the utmost importance for Carman to distinguish that "more than four-fifths of those involved were native born Americans," and that at "no other point of the war were both armies at so high a standard of men." ${ }^{107}$ This complimented the notion that the armies involved mastered the field tactically. This blanket praise for the soldiers fighting at Antietam was not enough; Carman went into specifics for each army to show why they represented the best stock of the Civil War.

The Union soldier fighting at Antietam was better than those that came after him because "there were no substitutes or mercenaries" according to Carman. ${ }^{108}$ Also, "all had volunteered from patriotism and an intense desire to save the Union." ${ }^{109}$ In addition to all of this, the men of the Army of the Potomac had morals that "were as good as those of any community" in America. ${ }^{110}$ The only weaknesses that Carman could find in the Union army

\footnotetext{
${ }^{105}$ Carman, Maryland Campaign, 270. Pierro, ed.

${ }^{106}$ Ibid., 213

107 Ibid.

${ }^{108}$ Ibid.

${ }^{109}$ Ibid.

${ }^{110}$ Ibid.
} 
were the new regiments who had not yet been drilled. Even these untested men all "stood their ground manfully." ${ }^{111}$ These blanket descriptors of the Union Army are surely not true representations of all who came to the field on September 17, 1862. But, this is the kind of framework that Carman wanted veterans to think of when they began conceptualizing their part in the battle.

The Confederates were given the same kind of praise of their Union counterpart. Carman viewed them as being "hard-fought battled" veterans. ${ }^{112}$ They were "not as well armed nor as well clothed and fed as their Union foes," but they fought on without complaint. Carman also extended a rather romantic image of them to his readers, stating that "men who at home had been masters of many slaves, or who were wealthy and lived in affluence without doing a day's work in their lives, [were] marching in the ranks barefooted, with ragged garments, carrying a musket and sleeping in the rain and mud."113 Even though they might not have displayed characteristics of a good American during the antebellum era, during war they too manifested the American spirit. Carman likely did not have this romanticized view of slaveholding Confederates when he met them in combat decades before, but by the 1890s he was comfortable enough with this memory of Confederates to place it in his manuscript. His historical work within a tactical framework memory had imparted a past different than the reality he lived. The same types of mental gymnastics are evident in Union and Confederate soldiers writing to Carman in the last years of the nineteenth century. They clearly understood

\footnotetext{
${ }^{111}$ Ibid.

${ }^{112}$ Ibid.

${ }^{113}$ Ibid.
} 
the atmosphere of their evolving nation and were wrestling to order their lived past within the changing present.

The vast majority of veterans writing to Carman chose to tailor their memories to the scaffolding created for them. They talked about tactics, bravery, heroism, and the glory of battle. These type of memories came together to dominate the narrative and memory of Antietam. The result of this was the establishment of definitive characteristics of America. In their own way they were telling the nation what it meant to be a good citizen. Exhibition of "dogged determination, good fighting qualities, splendid charges under terrific fire, and gallant leadership were things that any soldier would have been proud to have a place in," according to one veteran. ${ }^{114}$ They reaffirmed the notion that as a country America often defined itself through its wars, and they had participated in its purest battle of the greatest war to date. Thus, they became relics that all could look to for inspiration and pride.

A soldier in the $107^{\text {th }}$ Pennsylvania Infantry exemplified this when he recalled to Carman the bravery shown by individual soldiers around him. He described the fighting in the East Woods and the ensuing rush into the cornfield, primarily focusing on tactical maneuvers that he observed that day. But still, the memories that he shared with Carman often focused on the heroic and selfless moment. He spent considerable time speaking about rebel artillery shells landing around him and seeing a "brave fellow grab a burning fuse and extinguishing it before it could explode and kill his comrades." ${ }^{115}$ This soldier also took a considerable amount of time to describe the bravery of himself and two other comrades who put themselves in harm's way to

\footnotetext{
114 “De Rosset to Carman," No Date. NARA, RG 94 (AS). Reel 2, 741.

115 “J.C. Delaney" 27 March 1891. Taken from H.Net, Memories of America's Bloodiest Day: A veteran of Antietam spent his life collecting accounts of the war's most horrific fighting. Accessed 31 January 2011. This was an article written by prominent Antietam scholar Tom Clemens that shared several of Carman's letters and promoted the upcoming release of his edited treatment of Carman's manuscript.
} 
save their colors as they fell back. He explained to Carman that as his unit fell back he saw that their flag was being left behind under a pile of dead men. Upon this realization the soldier yelled to a few of his friends and he stated that "as quick as I could throw my voice to them that our flags were still on the ground, they both came bounding back and in an instant we pulled them out and with our hearts in our mouths dashed away." 116 This was the ultimate form of bravery and demonstrated willingness for self sacrifice to preserve honor.

Confederate veterans had similar views as to what characteristics a soldier should have displayed on the battlefield. Those who remained within Carman's framework remembered similar episodes. One veteran of the $3^{\text {rd }}$ North Carolina spoke of "a prompt coming to the front,

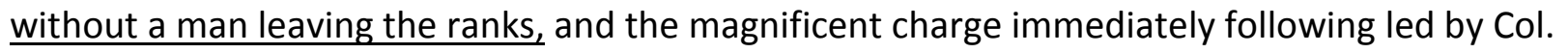
Thurston with the battle-flag in his hand, formed a picture in which any solider would feel proud to have a place."117 This detailed description was not repeated by Carman in his narrative, but Thruston's bravery and good soldiering did come through. Carman wrote that "the Confederate regiment was thrown into some confusion. . and it gave ground, but was rallied and steadied by Major Stephen D. Thruston." ${ }^{118}$ Thruston was thus immortalized on paper for his ability to lead men through the hard fought engagement.

Another veteran of the Army of Northern Virginia wrote to Carman of the type of man that he should rely on for information regarding Antietam. He recommended a second lieutenant who "was present upon the field the whole day and who was a most gallant and meritorious soldier and officer who fought to the finish and was paroled at Appomattox Court

\footnotetext{
116 Ibid.

117 “DeRosset to E.A. Carman," 1 June 1886. . NARA, RG 94 (AS). Reel 2, 740.

${ }^{118}$ Carman, Maryland Campaign, 238. Pierro, ed.
} 
House." ${ }^{119}$ Only the memories of men who had proven their bravery in combat were worthy of having a place in the official memory. This is why it was so important for men writing to Carman to stress to him what they believed bravery was and to demonstrate that they fit the bill. The type of man described as reliable fits Carman's description of the high quality soldiers in his manuscript.

Countless episodes of bravery are depicted by Carman in history that mirror or reaffirm episodes like those just mentioned. The courage of officers was often central to Carman's descriptions. They often are seen bravely leading their men and "examining the ground over which they would send their men." ${ }^{120}$ Many times these men were wounded as they selflessly undertook their "most important duty." 121 Once officers' assessments were made and the orders given, the men were described as deploying into "brilliant and bloody advances." 122 The rank-in-file soldiers who possessed all of the attributes needed to be considered excellent soldiers were led by men who displayed the same qualities.

Carman wrote these kinds of descriptions partially because veterans' memories were compelling him to do so. Letters from a Third North Carolina veteran urged that Carman revisit his own memories, "You who, witnessed the scenes, I have described, up to the time of your fall, must give up your views so that I may know whether we saw things through the same media." ${ }^{123}$ Perhaps the veteran hoped that this exercise would force Carman to reevaluate his own ideas, or at least provide enough corroborating evidence to verify what Carman already thought to be true. This is but one example of the delicate position that Carman had as the

\footnotetext{
119 “ Richard Maury to E.A. Carman," 29 October 1897. NARA, RG 94 (AS). Reel 2, 110.

${ }^{120}$ Carman, Maryland Campaign, 218. Pierro, ed.

${ }^{121}$ Ibid.

${ }^{122}$ Ibid., 224.

123 "S.D. Thruston to E.A. Carman," 16 June 1896, AA, (CC).
} 
gatekeeper of thousands of memories coming in to him from all over the United States. His role was so daunting because he was continually urged to reconsider his own interpretations. Sometimes Carman was even forced to consider his own role in the battle.

In one letter from Louisianan W.E. Moore to Carman, he became excited because from their correspondence because he had discerned that it was Carman's regiment that his men faced during the battle. Moore's memory recalled personal dominance as he interpreted the confrontation, stating that: "That was our second bout that awful morning and we suffered severely again, but I think your losses were greatest in that collision for your lines finally began to yield and about that time our supports coming up taking our place." ${ }^{\prime 24}$ Still both men had bravely stood against each other so, Moore turned to a reconciliatory tone thanking "the power that then governed" for keeping both of them from the front for the remainder of the battle, and hoped that he could "live long enough to see the United Veteran Association embrace every true patriot and soldier that did what he conceived to be his duty then." ${ }^{125}$ Moore and Carman led their men against one another and saw the same horrors, but in this exchange it was important in Moore's memory for him to have emerged victorious. After moment of dominance he could think about reconciliation in which, hopefully, his exploits would have a place and that the power that then governed would return.

Carman would not find a place in the national memory for Moore's recollection of Confederate dominance on the field. Instead he took advantage of his position as historian to defend his unit's ( $13^{\text {th }}$ New Jersey) actions that day. In Carman's assessment his men were

\footnotetext{
124 "W.E. Moore to E.A. Carman," 20 January 1896, AA, (CC).

${ }^{125}$ W.E. Moore to E.A. Carman," 20 January 1896. AA (CC).
} 
green and "scarcely knew how to load their muskets." 126 Inexperience was compounded by the fact that the Confederates they faced were in perfect position to mow down their enemy. Carman remembered that his "men were being shot at by a foe they could not see, so perfectly did the ledge protect them." ${ }^{127}$ These factors forced Carman to order his men back in good order because "to hold them under fire would [have been] murder." 128 In the end Carman cited evidence from his superiors that buttressed his claims. The division commander assessed that "so strong was the enemy, that an addition of any force I could command would only have caused further sacrifice without gain." ${ }^{129}$ In this interpretation both Moore and Carman emerged as brave soldiers in control of the field. Moore's hope for all brave soldiers to have a place in the national memory would be perpetuated. This episode shows an excellent example of how two historical actors were both able to will their memory into the official history.

Many men, like Confederate veteran Y.J. Pope, admitted to Carman that old age and time away from the battle clouded their memory, "Now General, all these things happened nearly 32 years ago, \& if you do not object, I will call to my aid some old comrades in arms, and get their help in locating these matters. ..."130 Nevertheless, Pope, like so many other veterans writing to Carman not only acted like he had command during the pandemonium on September 17, 1862, but that decades later he still controlled the events. Exactly one week after Pope talked of the struggles of an aging mind he vividly wrote that "in memory now I can see a gallant Federal officer seize his colors and go at least five paces in front of his line, to encourage

\footnotetext{
${ }^{126}$ Carman, Maryland Campaign, 274. Pierro, ed.

127 Ibid.

128 Ibid

129 Ibid. Cited as Gordon to Alpheus Williams, 495.

130 "Pope to E.A. Carman," 13 March 1895. AA, (CC).
} 
his soldiers to move forward to attack us." ${ }^{131}$ Clearly Carman's tactical questionnaire jump started Pope's memory process and began a conversation among his fellow veterans that would help reconstruct their past and reunite their country.

Convergence on a memory that fit into Carman's tactical and ordered discourse is the important idea to be drawn from veteran correspondence; accuracy is really insignificant. By being able to make sense of madness and presenting what was believed to be an accurate description of their participation in the battle, the men were individually contributing to the reconciliation process. Historians Nina Silber and David Blight have both asserted that "forgetfulness, not memory," was the key to reconciliation between North and South during the period of Carman's research. ${ }^{132}$ This idea should be modified. There was indeed an aura of forgetfulness taking place regarding the polarized reasons for fighting, but there was more reprioritizing of memory and refocusing occurring than anything else. This is abundantly evident in the case of the Carman correspondence on behalf of Carman and his respondents. As veterans put pen to paper and "endeavored to live over again that $17^{\text {th }}$ day of September $1862, "$ they only appear to have forgotten what motivated them to take up arms in the first place. ${ }^{133}$ Caution should be taken before this is considered a type of amnesia. They did not speak of race, emancipation, or secession because they were not asked to. They were asked to remember the events of the battle, and in doing so they envisioned a foe that stood on the field before them and shared in the ordeal. Thus, they all entered into a fraternity bound by valor that few in the present could understand. This was not forgetting, but reprioritizing memories

\footnotetext{
131 “Pope to E.A. Carman,” 20 March 1895, AA, (CC).

${ }^{132}$ Nina Silber, The Romance of Reunion: Northerners and the South, 1865-1900 (Chapel Hill: The University of North Carolina Press, 1993), 4.

133 "Y.J. Pope to E.A. Carman," 20 March 1895, AA, (CC).
} 
according to what was asked and needed. If viewed in this light, memory was paramount to reconciliation, not forgetting.

One letter from Confederate veteran W.M Roberts encapsulates almost everything that Carman attempted to achieve with his rigidly framed conversation. It painted a picture of manhood and bravery from both sides and showed tones of reconciliation. In doing this it also revealed a cathartic experience for the writer in which he was able to relive the battle once more in his mind. Also revealed was the kindness and relationship that Carman wished to share with veterans. All of this was of course created within a tactical discussion:

That was a terrible day and yet a glorious exhibition of American manhood on both sides. I left a loved brother who sleeps in an unknown grave in the extreme northern borders of that East Wood, at least he fell there shot in the breast and expired in a moment, saying only to the chum by-his side "Abe I'm gone." But, I must stop. You have yourself to blame for having tempted me to "fight my battles over again" which I have never done before and you must pardon the numerous references to myself and what I did-(for that is nearly all I know about it). . . . accept the greeting and goodwishes of an old soldier and rebel. . . Thank you for the compliment to the fighting of the troops in the woods whom you call "No.1. ${ }^{134}$

This kind of response would stand as an example of success for Ezra Carman and what he was trying to accomplish. It contains tones of nearly everything that Carman received from veterans. Still, even though this letter retrospectively demonstrates all of the hues that Carman tried to bring to the tapestry of Antietam, it still cannot be stated with complete certainty that he used it as an historian. Yet, tones of it are spread throughout his history and preserved for future generations.

134 “W.M. Robinson to E.A. Carman,” 25 March 1891. NARA, RG 94 (AS). Reel 2, 254-55. 


\section{Chapter 5: Conclusion}

Ezra Carman's labor produced three tangible historical products. The first of these was the text for the nearly three-hundred cast iron War Department plaques that visitors still read today when visiting Antietam, South Mountain, Shepherdstown, or Harpers Ferry. Secondly, he assisted other members of the Antietam Board in the production of fourteen sequential maps that still stand as the best record of what happened in the battle. And finally, he turned what was initially supposed to be a small explanatory pamphlet of Antietam, into the massive 1,800 page manuscript on the battle that has been discussed throughout this study. The manuscript is considered by many to be the most enduring legacy of Carman.

These visible achievements are really not all that measure Carman's legacy, however. His methods as an historian, the rich collection of letters that he left, and the public interpretation of Antietam that he forged and presented for the United States' public memory are the cornerstones of his life's work. Each of these aspects of the man is difficult to engage and conceptualize. That is why many scholars who have focused on Carman, or Antietam, have avoided deep engagement of his work's larger implications. It cannot be debated that Carman's narrative of the battle is both accurate and extremely usable to understand the military history of Antietam. There is much more that this historian's work can contribute to the Civil War historiography though. Serious analysis of his work shows the ways in which an historical actor can establish a framework that sets the boundaries for discussion regarding a subject. It then shows the ways this conversation can be controlled, mediated, and then transferred into a public interpretation that Americans as a whole are comfortable with and will accept. As Carman stood sentry over his conversation he revealed a great deal about the 
American political culture at the end of the nineteenth century, but he also tapped directly into Civil War veteran's memories and provided generations after the war with a direct view into Antietam. In the process of accomplishing this he broadly established what kind of traits it took to be an American and perpetuated the already popular notion that America defined itself through her wars.

Historian Kurt Piehler has effectively argued in his book Remembering War the American Way that "war has [always] played a decisive role in shaping the developments of American society." ${ }^{135}$ From the Revolutionary War onward, each generation of Americans has seen its country enter into some form of large scale military engagement. Some generations' military exposure is certainly eclipsed by others, but nonetheless, as a country the United States seems to always be engaged in some sort of conflict. Often, these conflicts bring with them transformative change to society. The Revolution brought independence, the War of 1812 secured national legitimacy, the Mexican-American War expanded borders, the Civil War preserved the Union, the Spanish American War demonstrated a taste for democratic empire and market expansion, the Great War increased international power, World War II established a superpower, Korea and Vietnam highlighted the problems of being a superpower, and the first Iraq War showed the difficulties of being a world policeman. The current engagements in the Middle East point to continued problems with Islamic terrorism and preemptive measures to protect our citizens. In basically all of these wars the process of sorting out a national consciousness of the wars in their aftermath became just as important as the actual fighting. ${ }^{136}$

\footnotetext{
${ }^{135}$ Kurt Piehler, Remembering War the American Way (Washington, DC: Smithsonian Press, 1995), 2.

136 Ibid., 3.
} 
With regards to forming a national consciousness and public memory, the Civil War is the most foundational of all of these. The Revolution established the basic ideals that our country would adhere to, but it never really created the kind of united country that would compel the federal government step in and take steps to foster a national memory. The Civil War was the most brutal test that the United States faced as its own nation. In its aftermath one nation was formed, and the government took steps to actively commemorate the valor and sacrifice of the Americans who secured the uniting with their lives. Historians like Ezra Carman were on the frontlines of this campaign. They were led by the sensibility of the new United States, they listened to the directives of their government, and followed the winds of political culture to provide the scaffolding in which American collective identity would be built around and remembered.

There is no question that the framework established and the memories that came into it were in some ways influenced by contemporary social issues. Regardless, many of the recollections coming through were genuine memories of the Civil War that are of immeasurable value to scholars. Carman's work must be approached with this multi-dimensional understanding in mind. A keen eye is needed to see what is reflective of the time period being worked in, and what is reflective of the Civil War. In some instances this distinction cannot be made, nor should it be. There is naturally a lot of overlap between the two periods. It must be remembered that Civil War veterans did not become new individuals after the war. Once mustered out of service they went home with memories of the conflict etched into their minds for the rest of their life. The question raised about the Carman correspondence is not whether it has the ability to open a window to the war years, it certainly does. It simultaneously looks 
into both the war and post war society. The larger question raised is which memories are the more genuine reflections of the war: those that fit nicely into Carman's framework, or the rogue memories that talked about things that did not broach tactics or heroism?

The memories that followed Carman's framework are more reflective of society at the turn of the century than of the war because they were following the political culture of the times. Those memories of dissent provide the most realistic view into the Civil War. Historian Kurt Piehler has described the agenda of political leaders at the turn of the century in the following way:

In remembering the past, national political leaders at times wanted to define a less-inclusive vision of nationhood, one that remained wary of the new immigrants from southern and eastern Europe. Theodore Roosevelt and others advanced a new organic theory of nationalism that emphasized the need for unity among Americans and viewed participation in the military as one of the most important forms of service a loyal citizen could render to his country. ${ }^{137}$

Ezra Carman's conversations about Antietam prove that this theory of nationalism was a very real thing. The government put quite a bit of effort into securing these notions. Those veterans that looked Carman's framework squarely in the face and chose to go rogue presented more accurate memories of the Civil War itself. These memories were not so bound by heroism and bravery. They were not concerned with perpetuating notions of Americanism, nor were they concerned with glorifying warfare. Instead they chose to tell a true story of chaos, horror, and personal loss. While these memories largely found themselves shackled out of public view, they still emerged because of Carman's work and were made available to future generations.

Those who wholly followed Carman's discourse not only contributed to creating notions of nationalism in textual form. They also physically displayed what it was to be a new American

\footnotetext{
${ }^{137}$ Piehler, Remembering War, 78.
} 
in elaborate ceremonies such as multitude of monument dedications taking place in the era.

The dedication of the Fifteenth Massachusetts Regiment monument at Antietam in 1900 stands out as one being particularly full of national symbolism.

While on the surface ceremony was just a monument dedication, it was in reality a complex ceremony with multiple acts, each having a certain meaning. Ultimately the entire performance was a booster of Americanism. The excursion of the regiment from Worcester County, Massachusetts by boat and train from New England, to New York, Gettysburg, Antietam, and finally Washington, D.C. itself reflected a spiritual and patriotic pilgrimage. The participants were travelling to honor those who never returned home from the battlefield decades ago, but wanted to affirm the story they had created about their role in the war to future generations. The grandeur of their trip also portrayed a powerful and unified United States of America, which the veterans acknowledged in speeches, "Happily the bitter feelings engendered by the war have passed away, and we are now a unified people, having but one country and one flag which floats, thank God, over a nation of free men." ${ }^{138}$ The ceremony also reflected defense of a new imperial United States forged in the War of 1898, "Being thus, united, we are today the peer of any nation on the globe...we will stand together and defend the flag wherever it rightfully floats...." ${ }^{139}$ Further example of the patriotic meaning of the ceremony was the shrouding of their monument in a large American flag, and the climactic unveiling while a chorus sang "The Star Spangled Banner." It is apparent that there was more

\footnotetext{
${ }^{138}$ George W. Ward, History of the Excursion of the Fifteenth Massachusetts Regiment and its Friends to the battlefields of Gettysburg, Antietam, Ball's Bluff and the City of Washington, D.C: September 14-20, 1900 (Worcester, Massachusetts: E.B Wood Press, 1904), "Address of General John W. Kimball," 41. From the Antietam National Battlefield Archives, Sharpsburg, Md.

${ }^{139}$ Ibid.
} 
significance to this ceremony than the overall tone of Civil War remembrance found in the text would suggest, this was just as much a patriotic performance and a booster of nationalism.

The primary actors of the drama were the veterans and government officials who spoke at the dedication, however, many assumed secondary roles. The audience members, choral singers, press, Sharpsburg residents who cheered the arrival of veterans in front of decorated homes, sculptor, and even the wounded lion atop the memorial itself had a role in the performance (grievously wounded, yet brave and defiant) ${ }^{140}$. Even the description of the setting possessed dramatic devises of its own - "clear cool air, the sublime and beautiful vista of the Cumberland Valley, and tears pouring down veterans' faces." ${ }^{141}$ The moment of the dedication also held significance, "Thirty-eight years ago today, yes, this very hour, the $15^{\text {th }}$ Regiment Infantry Massachusetts Volunteers, upon this field and where we now stand, met and fought in deadly conflict...." ${ }^{142}$ All of these elements combined to allow men to formulate meaning in their life through "inherited conceptions found in symbolic form." ${ }^{143}$ The memorial ceremony was a living creature holding multiple meanings. The text of the ceremony and speeches held one meaning, and the actual performance held another. Both ran together to create an awesome display of Americanism. Ezra Carman's work both mirrored these ceremonies and fueled them.

\footnotetext{
${ }^{140}$ Excursion, "Remarks of Colonel Russell," 26.

${ }^{141}$ Ward, Excursion, 25.

${ }^{142}$ Excursion, "Kimball," 29.

${ }^{143}$ Burke, Cultural History, 37.
} 


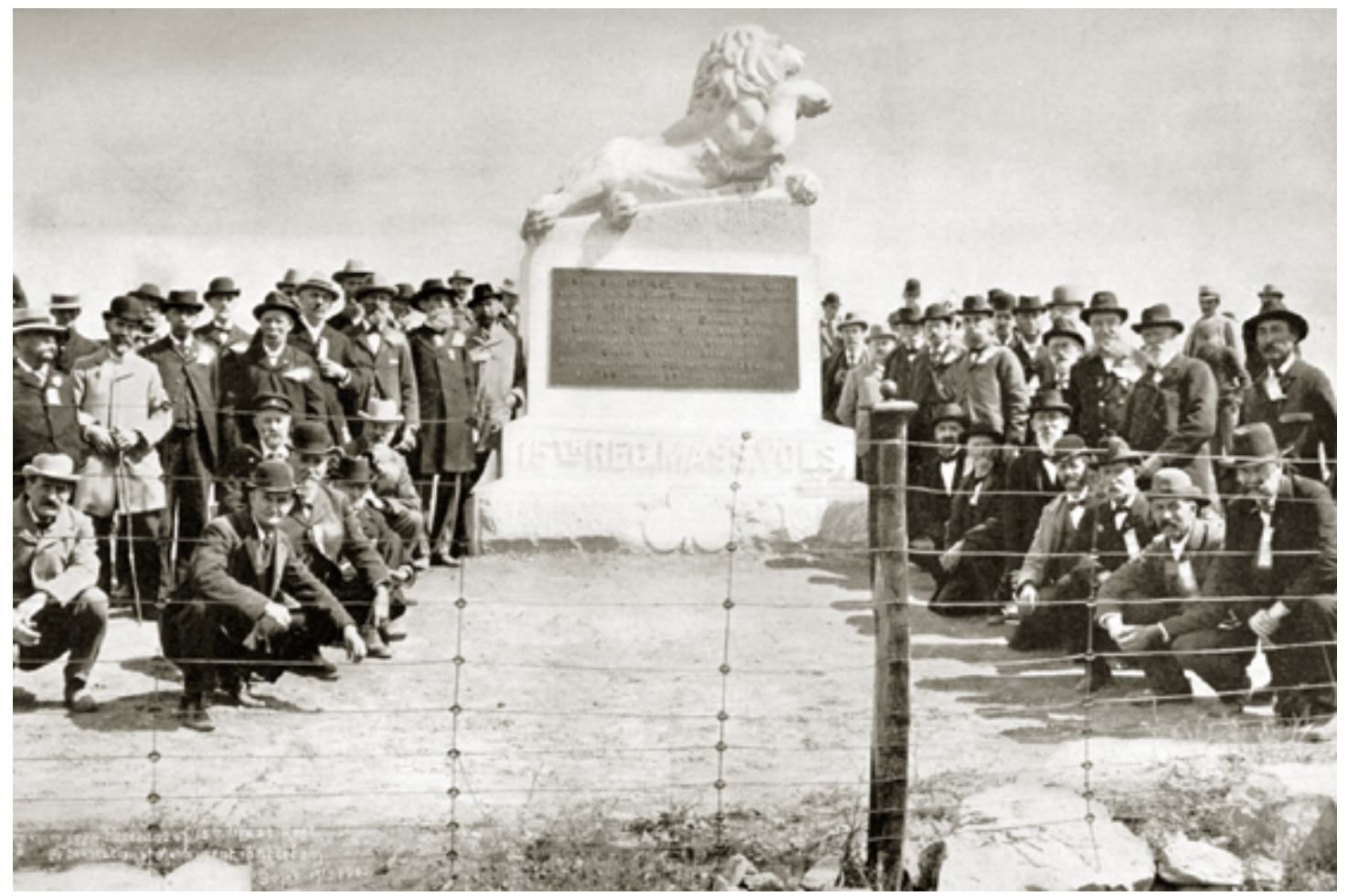

Image 5.1 "Dedication of the $15^{\text {th }}$ Massachusetts Memorial." Courtesy of Antietam National Battlefield.

The outset of the War of 1898 created an atmosphere in which it was even more enticing to focus on celebrating military tactics and the valor of American soldiers past and present. Nina Silber notes that "as the twentieth century began, northerners revealed a new respect for the South as an equal and willing partner in imperialist expansion." ${ }^{144}$ The monument dedication of the $15^{\text {th }}$ Massachusetts Infantry at Antietam on September 17, 1900 exhibits the idea of a unified imperial nation. This dedication, like so many others taking place at Antietam at the time, was full of patriotic symbolism and was essentially a booster of nationalism. At many of these dedications, including the $15^{\text {th }}$ Massachusetts, Ezra Carman was an active participant.

\footnotetext{
${ }^{144}$ Nina Silber, The Romance of Reunion, Northerners and the South 1865-1900 (Chapel Hill: The University of North Carolina Press, 1993), 11-12.
} 
This is fitting because his Antietam discourse became a main contributor to the reconciliatory, patriotic tone of the ceremonies.

Popular attitudes of glory and valor in military action would not begin to be seriously questioned by society until the staggering casualties of World War I were felt internationally. This war truly made the Victorian sensibility of Civil War veterans archaic. The irony of war and its aftermath, not glory and reconciliation, became the reason for soldiers to revisit their memories out of some kind of moral obligation. Paul Fussell addressed this issue in his seminal work The Great War and Modern Memory by showing the transformative interpretations of war by Ernest Hemingway: "Everyone knew that Glory was, and what Honor meant [before WWI]. It was not until eleven years after the war that Hemingway could declare in A Farewell to Arms that 'abstract words such as glory, honor, courage, or hallow were obscene beside the concrete names of villages, the numbers of roads, the names of rivers, the numbers of regiments and dates.'”145 Similarly, modernist writer William Faulkner captured the realism of social ignorance and man's continued inability to confront the serious issues in his 1940 novel The Hamlet when one of his characters thanked God that "men have done learned to forget quick what they ain't brave enough to try to cure." ${ }^{146}$ These literary examples from the early twentieth century stand as examples of the Victorian mind's inability to seriously engage war on a level that transcended the militaristic. Therefore, they also reveal the mental constraints that Carman and other veterans as they navigated and interpreted their memory of Antietam. They also explain the strict adherence to a military framework.

\footnotetext{
${ }^{145}$ Paul Fussell, The Great War and Modern Memory (New York and London: Oxford University Press, 1975$), 21$.

${ }^{146}$ William Faulkner, The Hamlet (1940). Taken from Warren Black, "Faulkner's Point of View," College English, vol.2, No 8 (May, 1941), 742.
} 
The work that Carman and his contemporary Civil War historians were undertaking at the end of the nineteenth century seems to be a very specific and isolated type of phenomenon. It was not, however. Their work was not bound by time or space at all. It was not only important to a public memory of America within national borders at the turn of the century, but also laid the foundation for powerful U.S. foreign relations in the preceding decades. The Federal government evaluated commemoration efforts following the Civil War as they undertook memorialization for new wars. Some parts of Civil War commemoration were seen as needing improvement, specifically the plethora of monuments that were allowed to be placed on battlefields. It was believed that this created a confusing experience for visitors and blocked any chance for a clear message to be taken home from the field. Following World War I, responsibility for U.S. commemoration abroad was taken from the War Department and placed in the hands of a new agency called the American Battle Monuments Commission (ABMC). Many of the policies adopted by the $A B M C$ and its historians were very similar to what Ezra Carman did at Antietam.

The American Battle Monuments Commission was created by an act of Congress on March 4, 1923. It was designed to be the sole caretaker for the memory of the United States in the Great War. General of the Armies John J. Pershing was selected to be the first chair of this prestigious organization, and he selflessly served until his death in 1948. The ABMC was tasked to landscape and construct a nonsectarian chapel in the eight cemeteries throughout Europe that the War Department had established to bury U.S. soldier dead of the Great War. It would also erect eleven separate monuments to U.S. valor. In 1934, the President officially transferred all responsibility for maintenance of the cemeteries to the ABMC and made it the 
agency responsible for the establishment of any future U.S. military burial grounds on foreign soil that may be necessary. With this executive order, the ABMC became the guardian and caretaker of American military memory abroad.

The $A B M C$ achieved these specific assignments, but it also undertook additional work. Perhaps the most ambitious undertaking of the post-WWI ABMC was the writing of a massive history/guidebook of the American Expeditionary Forces in World War I. This project was envisioned by General Pershing as being a travel companion to AEF veterans traveling abroad to visit battlefields in Europe in which their military was engaged. It would contain a narrative of what happened, maps of the battlefields, and appropriate photographs. The guidebook transformed into an enormous project. Pershing staffed a large historian office within the $A B M C$ to tirelessly research and write about the AEF abroad. The end result of the project was to stand as the definitive history of American in WWI, and it would have the endorsement and approval of the General of the Armies himself. The writing and research of this book moved at an unprecedented pace and involved many prominent young military officers. Dwight D. Eisenhower was one of the most active scholars involved in the project. He spent a lengthy amount of time abroad touring the battlefields and writing narratives of what had happened. When he commanded the Allies in World War II he had a very firm grasp on the military engagements that had taken place on the same fields decades before.

This ABMC's history strayed from what Carman undertook with his Antietam manuscript in obvious ways, yet it is quite similar. The ABMC's history was a chronicle of the entire war, it was envisioned as a travel companion, and many historians were working round the clock to finish the product. But fundamentally, the ABMC was following in the footsteps of Ezra 
Carman, particularly with regards to its use of correspondence and veterans memories. Like Carman, the ABMC opened up an extensive amount of correspondence with American WWI officers and asked for their recollections. And, like Carman, the ABMC framed its conversation with veterans in a way that did not allow much straying from tactical/military memories.

Pershing's secretary, Major Xenophon Price, was the ABMC's equivalent of Ezra Carman. It was Major Price who endorsed most of the correspondence with veterans and elicited followup responses. Price's primary means of initiating conversation with veterans came from a basic form letter. The ABMC would send a letter that asked basically the same tactical questions that Carman did. If they had already written a narrative of the event based on other research they would include their work with the letter to see if the veteran's memory was in accord. Also included would be a map of the terrain in question that was to be marked on by the veteran to show accurate movements on the field. A letter to Lt. Col. Frank Burnett, an American officer who was present for the first German raid on American troops in the Great War, gives a good example of the ABMC's tactics. In this letter Price included an essay written by ABMC historians entitled "The First Raid on American Troops" for the officer to read and comment upon. ${ }^{147}$ Burnett was "personally engaged in the encounter" and the ABMC wanted him to give "any comments or criticisms" the he cared to share about their essay. ${ }^{148}$ They also wanted him to make any appropriate marks on their "photostatic copy of the trench system present during the

${ }_{147}^{148}$ “X.H. Price to Frank Burnett,” 5 November 1927. Taken from NARA, RG 117, Officer Correspondence, Box 184. 
raid." 149 Burnett was assured by Price that "no comment or criticism" would be "unimportant or not of interest in [their] research."150

Like Carman, Price wrote in a way that showed complete respect for the veteran. Anything that he had to contribute would be welcome, but still, efforts were taken to keep his memory in the ABMC's realm. By including a written narrative of the engagement the historians at the $A B M C$ were giving the veteran something that would interact with his memories and keep them on track. The inclusion of a map of Burnett's trench system helped bind his memory to one small section of one battlefield. The correspondence nonetheless caused Burnett to do the exact same thing that many Civil War veterans writing to Carman did. He immediately took the ABMC's inquiry and sent it to comrades for their memories and recollections in order to test the accuracy of his own mind. In the end those individuals that Burnett shared his memories with agreed that "in short, your memory serves you correctly. . ."151 This affirmation allowed Burnett to confidently make very slight alterations to specifics of company designations made in the ABMC's report, but ultimately confirm to Price that he "found no other errors in the summary." ${ }^{152}$ This exchange shows a very efficient process adopted by the $A B M C$ history section, but also gives some indication that the $A B M C$ was pushing their own interpretation on veterans they spoke with.

It has been shown that Carman's inquiries often brought forth memories that did not remain within the framework that the government wanted. This was also the case with the $A B M C$ 's correspondence. Other officers involved in the same raid that Burnett was chose to go

\footnotetext{
149 Ibid.

150 Ibid.

${ }^{151}$ Kingman to Burnett," 20 November 1927. Taken from NA, RG 117, Officer Correspondence, Box 184.

152 “Burnett to Price," 6 December 1927. Taken from NA, RG 117, Officer Correspondence, Box 184.
} 
into much more detail with their responses to Price. William McLaughlin's account of the raid was incredibly detailed and highlighted the inherent confusion of trench warfare and the lack of glory in battle. McLaughlin began his account of the German raid by describing their initial shelling of the American position: "the first shell came in. . . it was followed by two more in quick succession and these two were followed by three more, and then-CHAOS."153 The concussion of these exploding shells knocked McLaughlin to the ground and he admitted to experiencing "violent spells of nausea." 154 Once he was able to regain his composure he remembered becoming alert and "squirming out from under Cpl. Gresham who had been killed by being shot between the eyes...," after this he took a drink from his canteen "which seemed to be the most important thing in the world at the time." ${ }^{155}$ He then began moving through the trench system to assess the situation, walking over American casualties. His memory then focused vividly on the violent scene in the trench. He recollected a stairway "red with blood, and American and German equipment scattered all over the place.."156 One of the American rifles was broken at the stock and partially covered "with blood and hair." 157

This account recreated the chaos of war effectively, and it appeared to be extremely accurate. McLaughlin still had his field message book from the night in his possession, and demonstrated in his narrative that he had communicated with other Americans involved in the raid. He also submitted a photograph of the American soldiers that the German's captured in the raid. Just as Carman would not have been able to use such a graphic and detailed account from a Civil War veteran of Antietam, the ABMC could not use McLaughlin's. They were

\footnotetext{
153 “McLaughlin to Price," 5 December 1927.

${ }^{154}$ Ibid.

${ }^{155} \mathrm{Ibid}$

${ }^{156}$ Ibid.

${ }^{157}$ Ibid.
} 
courteous of his response nonetheless, stating that "your extremely interesting comments will make a valuable addition to the files [emphasis added] of the Commission and will be of material assistance in making final decisions on this matter."158 McLaughlin's response to the ABMC and their subsequent response show a continuum from Carman's work with Civil War memory to the ABMC's work with Great War memory. McLaughlin's message was both useful and powerful, but it strayed from the established discourse. American culture had changed a great deal since the Civil War and the public was more aware that modern battle was not glorious, but the government still wanted to convey military greatness in the public's memory of American warfare.

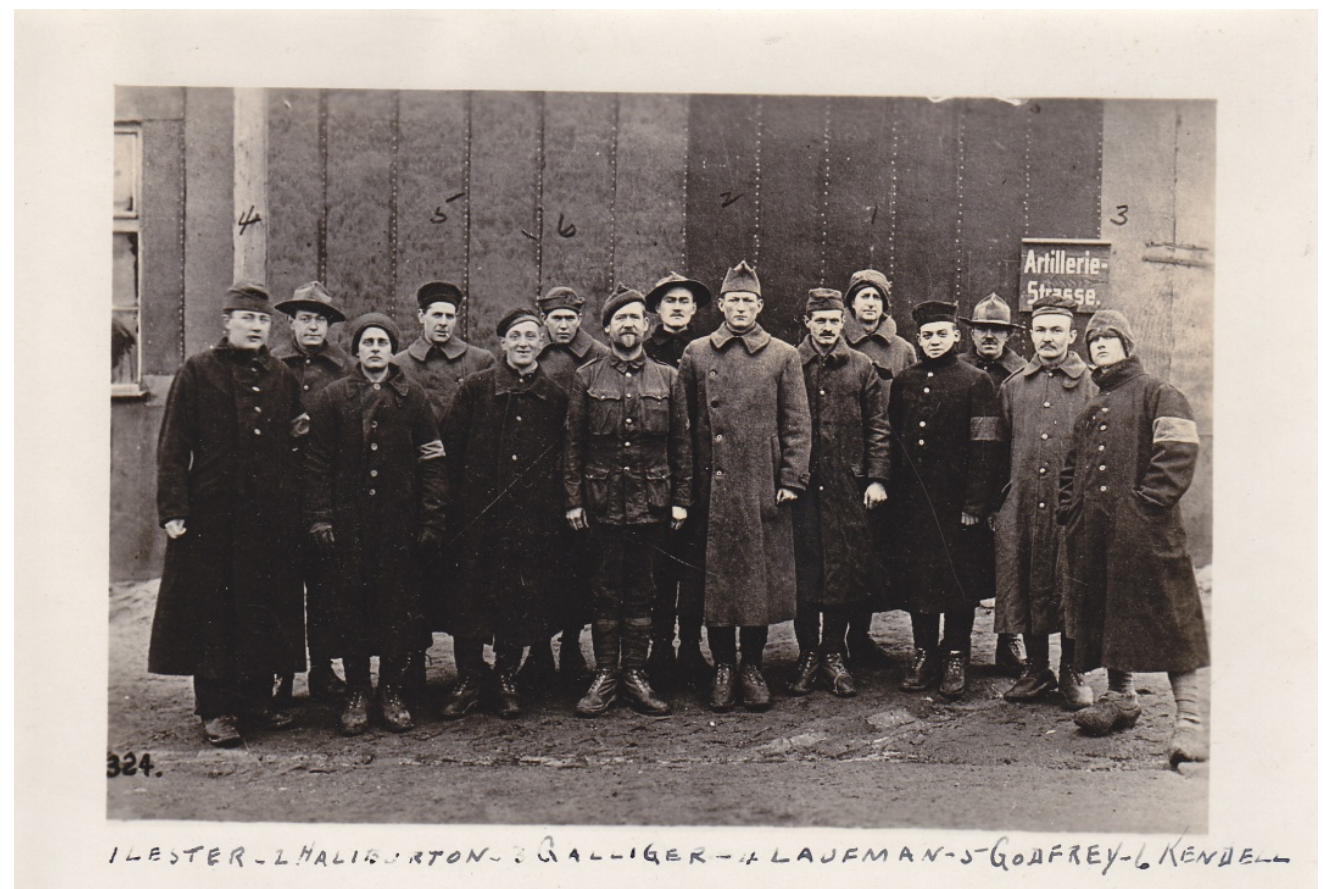

Image 5.2 McLaughlin included this picture with his letter to Price. He wrote labeled it as: "Picture taken in Russian Poland, showing therein six of the first eleven American soldiers captured by the Germans. This picture was given to me by John Lester, Batesville, Mississippi-shown as number one in the picture. Lester was Platoon Runner for the first platoon." NARA, RG 117, Officer Correspondence.

158“ Price to McLaughlin”, 28 December 1927. 
Historian Carol Reardon's has spoken to why the memory of U.S. wars are placed in a predominately military spheres of heroism and bravery, "The most enduring moments that claim places in American public memory-these images that best capture and hold longest the popular interest-possess the ability to bridge past and present." ${ }^{159}$ During the war soldiers needed to have control over the chaos of the battlefield and after the war this remained true. Military tactics, maneuvers, and casualties could be recollected with clarity, whether true clarity or invented clarity is inconsequential. Causes of the war and political consequences of the battle of Antietam were something that a soldier had no control over. This is why large political issues such as race and emancipation were absent from Carman's discourse and why they were meager in his field markers and narrative. It is also why the ABMC did not get involved with interpreting the controversial American entrance into the Great War. The nation quite literally shared in the bloodletting of its battles. American soldiers took up arms for their country and never returned home. The carnage was something that all soldiers could take a morbid comfort in-it somehow evolved to mirror sentimental impressions of beauty. The "carnival of death and suffering" became the most enduring moment and offered the most practicable way of bridging past and present while capturing public interest at the same time. ${ }^{160}$

Ezra Carman's facilitation of a medium for Antietam veterans to replay decade old memories of often small individually lived experiences opened a window into the reunion culture of the United States that few have chosen to look through. It also stands as an example of how the United States government would continue to commemorate and render public memory of its wars. How they attempted to temper the ways veterans remembered and their

\footnotetext{
${ }^{159}$ Carol Reardon, Pickett's Charge in History and in Memory (Chapel Hill, UNC Press, 1997), 3.

${ }^{160}$ Carman, Maryland Campaign, 363. Pierro, ed.
} 
prioritization of memories are representations of the culture they lived in and the ways their worlds were perceived. Carman's scrutiny and guidance of the memories for his metanarrative gives further explanation to the national character. The decision that Carman made as he stood guard at the gateway to Antietam's memory to keep the conversation in the realm of tactics was much more powerful than anyone, even Carman himself, likely could have comprehended at the time. Carman could only let through what the sentiment of his times would allow. He was not acting in bad faith, consciously suppressing memories, or asserting unchecked power. Yet, the political culture of his time guided his observations and the sense that he made of them. ${ }^{161}$ This is why Antietam is synonymous as the bloodiest day in American history.

Even though this effort to bind memory in the tactical realm was implemented and brought tangible success, it was not completely victorious. Carman's discourse melted together private memories and created a unified public memory of Antietam, and the Civil War that focused on military heroism. Yet, it also engaged individual memories that refused to tailor their memories to something that they did not feel was true. These memories are of equal or greater value to those that conform. They seem to be the only ones that tell a true story of the war and offer a glimpse into the war years. Carman was not a failure for sidelining these memories; he was just bound by the political culture of his time.

The nation could find common ground in the carnival of suffering and had an opportunity to come together in consensus. The Emancipation Proclamation that resulted from the battle was the first domino to fall in a steady continuation of complicated racial relations in the United States. At the turn of the century the complicated motives for fighting the Civil War,

${ }^{161}$ Willie Thompson, Postmodernism and History (New York: Palgrave MacMillan, 2004), 83. 
race relations, and rapid changes of modernization were confusing issues that would do nothing but divide. Veterans, like other citizens of the United States, had little control over these elements of society. Grand tactics and individual valor were familiar territories that all Americans could be proud of. Because of this, "the bloodiest day in American history" became something much more applicable and relevant than "the day that ushered in emancipation." 


\section{Bibliography}

\section{Archival Primary Sources}

Antietam Archives (AA). Sharpsburg, Maryland.

"Ezra Carman Correspondence. (CC)"

"General Carman's Response, Accepting the Gift, On Behalf of the Government," Dedication of the $34^{\text {th }}$ New York Infantry Monument.

Ward, George. History of the Excursion of the Fifteenth Massachusetts Regiment and its Friends to the battlefields of Gettysburg, Antietam, Ball's Bluff and the City of Washington, D.C: September 14-20, 1900. Worcester, Massachusetts: E.B Wood Press, 1904. From the Antietam National Battlefield Archives, Sharpsburg, Md.

George C. Marshall Research Library (GML). Lexington, VA.

Papers of George C. Marshall. "American Battle Monuments Commission." Box 161 Folders 1-9.

National Archives (NARA). Washington, D.C. and College Park, MD.

Antietam Battlefield Board Papers, Series 706, Record Group 92.

Antietam Battlefield Board Papers, Series 707, Record Group 92.

Antietam Studies (AS), Record Group 94. Microfilm.

Records of the American Battle Monuments Commission. "Pershing Correspondence File." Record Group 117 Boxes 7-8.

AEF Division Officers Correspondence." RG 117.

\section{Published Primary Sources}

Carman, Ezra Ayers. Thomas Clemens, Ed. The Maryland Campaign of September 1862:

Volume I, South Mountain. New York: Savas Beatie, 2010.

"A Letter from Lewis Reed $12^{\text {th }}$ Massachusetts Infantry." 13 April 1894. Taken from Tom Clemens's internet blog, The Maryland Campaign of September 1862, http://marylandcampaign.com/blog-posts/. 
"Carman to Colonel S.E. Pittman," 3 May 1897. Taken from Dr. Tom Clemens's blog The Maryland Campaign of September 1862, http://marylandcampaign.com/. Accessed on 29 January 2011.

Carman, Ezra Ayers. Ed. Joseph Pierro. The Maryland Campaign of September 1862: Ezra A. Carman's Definitive Study of the Union and Confederate Armies at Antietam. New York: Routledge Press, 2008. Original Carman manuscript unpublished.

Magilton, Albert. Second Brigade of the Pennsylvania Reserves at Antietam: Report of the Antietam Battlefield Memorial Commission of Pennsylvania and Ceremonies at the Dedication of the Monuments Erected by the Commonwealth of Pennsylvania to Mark the Position of Four Regiments of the Pennsylvania Reserves Engaged in the Battle. Harrisburg, PA: Harrisburg Publishing Company, State Printer, 1908.

Bland, Larry, ed. The Papers of George Catlett Marshall, vol. I: The Soldierly Spirit, December 1880-June 1939. Johns Hopkins University Press: Baltimore and London, 1981.

The Papers of George Catlett Marshall, vol. II: We Cannot Delay, July 1, 1939-December 6, 1941. Johns Hopkins University Press: Baltimore and London, 1986.

The Papers of George Catlett Marshall, vol. IV: Aggressive and Determined Leadership, June 1, 1943-December 31, 1944. Johns Hopkins Press: Baltimore and London, 1996.

Cullum, George (Brevet-Major-General). Biographical Register of the Officers and Graduates of the U.S. Military Academy at West Point, New York Since its Establishment in 1802. Supplement, Volume VI-B 1910-1920. Colonel Wirt Robinson, ed. Seemann \& Peters, Printers: Saginaw, Michigan, 1920.

Supplement, Volume VII 1920-1930. Captain WM.H Donaldson, C.A.C. R.R. Donnelley \& Sons Company, The Lakeside Press: Chicago, Illinois, and Crawfordsville, Indiana, 1930.

Supplement, Volume VIII 1930-1940. Lt.-Col. E.E. Farman, ed. R.R. Donnelley \& Sons Company, The Lakeside Press: Chicago, Illinois, and Crawfordsville, Indiana, 1940.

American Battle Monuments Commission. American Armies and Battlefields in Europe: A History Guide and Reference Book. United States Government Printing Office: Washington D.C., 1938. Reprinted by The United States Army Center of Military History: Washington, D.C., 1992.

Pershing, John J. "Our National War Memorials in Europe." The National Geographic. The National Geographic Society, LXV, no. 1. January 1934.

United States Government Printing Office. American Battle Monuments Commission: Hearings Before the Committee on Foreign Affairs, House of Representatives, Sixty-Seventh 
Congress, Second and Third Sessions on H.R. 9634 and H.R. 10801. March 15-20, November 28, December 7-9, 1922. GPO, 1922.

United States Government Printing Office. Annual Report of the American Battle Monuments Commission to the President of the United States: Fiscal Year 1926. GPO, 1927.

\section{Secondary Sources}

Ayers, Edward. What Caused the Civil War? Reflections on the South and Southern History. New York and London: WW Norton \& Co., 2005.

Blight, David. Race and Reunion: The Civil War in American Memory. Harvard University: Cambridge, Massachusetts, 2001.

Brundage, Fitzhugh. "No Deed but Memory." taken from Where These Memories Grow: History, Memory, and Southern Identity. Chapel Hill: UNC Press, 2000.

Burdreau, Lisa. "The Politics of Remembrance: The Gold Star Mothers' Pilgrimage and America's Fading Memory of the Great War." The Journal of Military History, vol. 72, no. 2, April 2008. Bruce Vandervot, ed. Published Quarterly for the Society for Military History by the George C. Marshall Foundation and Virginia Military Institute.

Burke, Peter. What is Cultural History? Cambridge: Polity Press, 2008 2ed.

Burton, Antoinette. 2005. Archive Stories Facts, Fictions, and the Writing of History. Durham, NC: Duke University Press.

Fahs, Alice. The Imagined Civil War: Popular Literature of the North \& South, 1861-1865. Chapel Hill: UNC Press, 2001.

Faulkner, William. The Hamlet. Random House Publishing, 1940.

Funck, Marcus, Greg Eghigian, and Matthew Paul Berg. Sacrifice and National Belonging in Twentieth-Century Germany. Walter Prescott Webb memorial lectures, 34. College Station: Texas A \& M, 2002.

Fussell, Paul. The Great War and Modern Memory. New York and London: Oxford University Press, 1975.

Gallagher, Garry and Alan Nolan, eds. The Myth of the Lost Cause and Civil War History. Indianapolis: Indiana University Press, 2000.

The Antietam Campaign. Chapel Hill: UNC Press, 1999. 
Grow, Matthew J. "The Shadow of the Civil War: A Historiography of Civil War Memory." American Nineteenth Century History. Vol. 4, No. 2, Summer 2003.

Grubrich-Simitis, Ilse. Translated by Philip Slotikin. Back to Freud's Texts: Making Silent Documents Speak. Yale University Press, 1996.

Hess, Earl J. The Union Soldier in Battle. Lawrence: The University Press of Kansas, 1997.

Houghton, Walter. The Victorian Frame of Mind, 1830-1870. New Haven: Yale University Press, 1957.

Kahn, Michael. Basic Freud: Psychoanalytic Thought for the Twenty First Century. New York: Basic Books, 2002.

Kammen, Michael. Mystic Chords of Memory: The Transformation of Tradition in American Culture. New York: Knopf, 1991.

Kaplan, Amy, and Donald E. Pease. Cultures of United States Imperialism. New Americanists. Durham: Duke University Press, 1993.

Lears, T. Jackson. "The Concept of Cultural Hegemony." American Historical Review, 1985.

Linderman, Gerald F. Embattled Courage: The Experience of Combat in the American Civil War. New York: Free Press, 1987.

Linenthal, Edward Tabor. Sacred Ground: Americans and Their Battlefields. Chicago: University of Illinois Press, 1991.

Maier, Charles S. The Unmasterable Past: History, Holocaust, and German National Identity. Cambridge, Mass: Harvard University Press, 1988.

Margalit, Gilad. Guilt, Suffering, and Memory: Germany Remembers its Dead of World War II. Bloomington: Indiana University Press, 2010.

McPherson, James. For Cause \& Comrades: Why Men Fought in the Civil War. New York and Oxford: Oxford University Press, 1997. Crossroads of Freedom: Antietam. Oxford: Oxford University Press, 2002.

Moeller, Robert G. War Stories the Search for a usable past in the Federal Republic of Germany. Berkeley: University of California Press, 2001. 
Neff, John R. Honoring the Civil War Dead: Commemoration and the Problem of Reconciliation. Modern war studies. Lawrence: University Press of Kansas, 2005.

Nishiura, Elizabeth. American Battle Monuments: A Guide to Military Cemeteries and Monuments Maintained by the American Battle Monuments Commission. Omnigraphics, Inc.: Detroit Michigan, 1989.

Niven, William John. Germans as Victims: Remembering the Past in Contemporary Germany. Basingstoke [England]: Palgrave Macmillan, 2006.

Niven, William John, and Chloe E. M. Paver. Memorialization in Germany since 1945. Basingstoke [England]: Palgrave Macmillan, 2010.

Nora, Pierre. "Between Memory and History: Les Lieux de Memoire. "Representations. No. 26, Special Issue: Memory and Counter-Memory. Spring, 1989. 7-24.

Piehler, G. Kurt. Remembering War the American Way. Washington, D.C.: Smithsonian Press, 1995.

Pogue, Forrest C. George C. Marshall: Education of a General (1880-1939) Vol. 1. New York, Penguin Books, 1963.

George C. Marshall: Ordeal and Hope (1939-1942). Vol. II. New York, Penguin Books, 1966.

George C. Marshall: Organizer of Victory (1943-1945). Vol. III. New York, Penguin Books, 1973.

George C. Marshall: Statesman (1945-1959). Vol. IV. New York, Penguin Books, 1987.

Prince, K. Michael. War and German Memory: Excavating the Significance of the Second World War in German Cultural Consciousness. Lanham, MD: Lexington Books, 2009.

Reardon, Carol. Pickett's Charge in History and in Memory. Chapel Hill: The University of North Carolina Press, 1997.

Savage, Kirk. Standing Soldiers, Kneeling Slaves: Race, War, and Monument in NineteenthCentury America. Princeton University Press, 1997.

Scully, John Connor. Ezra Carman: Soldier and Historian (M.A. Thesis). Fairfax, Virginia: George Mason University, Fall Semester 1997.

Sears, Stephen. Landscape Turned Red: The Battle of Antietam. New Haven and New York: Tickner and Fields, 1983. 
Silber, Nina. The Romance of Reunion, Northerners and the South 1865-1900. Chapel Hill: The University of North Carolina Press, 1993.

Singal, Daniel. The War Within: From Victorian to Modernist Thought in the South, 1919-1945. Chapel Hill: The University of North Carolina Press, 1982.

Sledge, Michael. Soldier Dead: How We Recover, Identify, Bury, and Honor Our Military Fallen. New York, Columbia University Press, 2005.

Smith, Timothy. The Golden Age of Battlefield Preservation: The Decades of the 1890s and the Establishment of America's First Five Military Parks. Knoxville: The University of Tennessee Press, 2008.

Smythe, Donald. Pershing: General of the Armies. Indiana, University of Indiana Press, 1986.

Snell, Charles. Antietam National Battlefield and Cemetery, Sharpsburg, Maryland: An Administrative History. Washington, DC: The U.S. Department of Interior/National Park Service, 1986.

Snell, Mark ed. Unknown Soldiers: The American Expeditionary Forces in Memory \& Remembrance. Kent, Ohio: Kent State University Press, 2008.

Thompson, Willie. Postmodernism and History. New York: Palgrave MacMillan, 2004.

Trouillot Michel-Rolph. Silencing the Past: Power and the Production of History. Boston: Beacon Press, 1995.

Trout, Steven. On the Battlefield of Memory: The First World War and American Remembrance, 1919-1941. Tuscaloosa, Alabama: The University of Alabama Press, 2010

Ural, Susannah. The Harp and the Eagle: Irish American Volunteers and the Union Army, 18611865. New York: NYU Press, 2006.

Vandiver, Frank. Black Jack: The Life and Times of John J. Pershing. Texas A\&M Press: College Station, 1977.

Wickberg, Daniel. "What is the History of Sensibilities? On Cultural Histories, Old and New." The American Historical Review, 2004.

Winter, Jay. Remembering War: The Great War Between Memory and History in the Twentieth Century. New Haven Connecticut: Yale University Press, 2006. 